\title{
Bioactivities, Applications, Safety, and Health Benefits of Bioactive Peptides From Food and By-Products: A Review
}

\author{
Ahmed A. Zaky ${ }^{1 *}$, Jesus Simal-Gandara ${ }^{2}$, Jong-Bang Eun ${ }^{3}$, Jae-Han Shim ${ }^{4 *}$ and \\ A. M. Abd El-Aty ${ }^{5,6 *}$ \\ ${ }^{1}$ National Research Centre, Department of Food Technology, Food Industries and Nutrition Research Institute, Cairo, Egypt, \\ ${ }^{2}$ Nutrition and Bromatology Group, Department of Analytical Chemistry and Food Science, Faculty of Science, Universidade \\ de Vigo, Ourense, Spain, ${ }^{3}$ Department of Food Science and Technology, Chonnam National University, Gwangju, \\ South Korea, ${ }^{4}$ Natural Products Chemistry Laboratory, Biotechnology Research Institute, Chonnam National University, \\ Gwangju, South Korea, ${ }^{5}$ Department of Pharmacology, Faculty of Veterinary Medicine, Cairo University, Giza, Egypt, \\ ${ }^{6}$ Department of Medical Pharmacology, Medical Faculty, Ataturk University, Erzurum, Turkey
}

OPEN ACCESS

Edited by:

Marcello Iriti,

University of Milan, Italy

Reviewed by:

Domancar Orona-Tamayo,

Centro de Innovación Aplicada en

Tecnologías Competitivas

(CIATEC), Mexico

Milica Pavlicevic,

University of Belgrade, Serbia

*Correspondence:

Ahmed A. Zaky

dr.a.alaaeldin2012@gmail.com

Jae-Han Shim

jhshim@jnu.ac.kr

A. M. Abd El-Aty

abdelaty44@hotmail.com

Specialty section:

This article was submitted to Food Chemistry,

a section of the journal

Frontiers in Nutrition

Received: 15 November 2021 Accepted: 30 December 2021

Published: 20 January 2022

Citation:

Zaky AA, Simal-Gandara J, Eun J-B,

Shim J-H and Abd El-Aty AM (2022) Bioactivities, Applications, Safety, and Health Benefits of Bioactive Peptides

From Food and By-Products: A

Review. Front. Nutr. 8:815640.

doi: 10.3389/fnut.2021.815640
Bioactive peptides generated from food proteins have great potential as functional foods and nutraceuticals. Bioactive peptides possess several significant functions, such as antioxidative, anti-inflammatory, anticancer, antimicrobial, immunomodulatory, and antihypertensive effects in the living body. In recent years, numerous reports have been published describing bioactive peptides/hydrolysates produced from various food sources. Herein, we reviewed the bioactive peptides or protein hydrolysates found in the plant, animal, marine, and dairy products, as well as their by-products. This review also emphasizes the health benefits, bioactivities, and utilization of active peptides obtained from the mentioned sources. Their possible application in functional product development, feed, wound healing, pharmaceutical and cosmetic industries, and their use as food additives have all been investigated alongside considerations on their safety.

Keywords: bioactive peptides, health benefits, bioactivities, applications, safety

\section{INTRODUCTION}

Nowadays, food is recognized as a source of dietary substances and biologically active compounds that improve human health and the general conditions of the organism. The consumers' increasing awareness of the influence of diet on health is reflected in their selection of natural products, abundant in vitamins, minerals, and other bioactive compounds like carotenoids (1), anthocyanins (2), polyphenols (3), or peptides $(4,5)$.

Bioactive peptides are protein fragments that benefit the body systems and overall human health. Most bioactive peptides range between two (dipeptides) and 20 amino acid residues and have a molecular mass of $0.4-2 \mathrm{kDa}$ (6). Longer peptides have also been reported in rare cases. Lunasin, for example, is a peptide formed by 43 amino acids produced from soy, which demonstrates anti-cancer and hypocholesterolemic properties (7).

Bioactive peptides generated from food possess an excellent potential for creating functional foods and/or nutraceuticals to prevent or treat some chronic diseases (8). Many articles on the generation and characterization of bioactive peptides with antimicrobial, anti-inflammatory, antihypertensive, anti-obesity, and antioxidant attributes have been published (9). Herein, we 
focused on bioactive peptides from different foods and their by-products, their effects on health, and possible applications.

In this investigation, eligible studies (in English) were acknowledged during an electronic search of the PubMed database (1991-2021) (https://www.nlm.nih.gov/) and Google. We employed the chief search word "bioactive peptides" along with the words "sources," "by-products," "extraction," "purification," "identification," "bioactivities," "health effects," "pharmaceutical applications," "food applications," "cosmeceutical applications," "feed applications," and "safety" to find the relevant articles. We selected the titles, keywords, and abstracts of the articles collected from the database. Several review articles were omitted in favor of the primary sources cited.

\section{THE SOURCES OF BIOACTIVE PEPTIDES}

Peptides and proteins are critical macronutrients as they provide the necessary raw materials for protein production and serve as a source of energy. Bioactive peptides have been isolated or produced from various plant and animal sources (Tables 1-4). Food proteins are chosen as a reference for bioactive peptides based on two factors: (i) a desire to add value to abundant underused proteins or protein-rich industrial food waste, and (ii) the use of proteins with particular peptide sequences or amino acid residues with specific pharmacological benefits (87).

\section{Extraction of Bioactive Peptides}

Bioactive peptides are conventionally isolated by chemical or enzymatic hydrolysis and fermentation. To enhance the degree of hydrolysis in the generation of bioactive peptides, new approaches, such as microwave, ultrasound-assisted extraction, ohmic heating, pulsed electric fields, and subcritical water hydrolysis, have been investigated (88). Physical processes are at the core of these techniques (Figure 1).

\section{Chemical Methods}

Chemical techniques using alkalis, such as sodium hydroxide, are the most typical and conventional method for protein extraction from plant sources $(89,90)$. It can effectively break hydrogen and amide bonds to solubilize rice bran proteins. Although this process is highly effective in obtaining most proteins in a soluble form, it creates specific structural changes that cause a protein to lose its original function (91).

\section{Enzymatic Methods}

Enzymatic hydrolysis is another common approach for separating proteins and hydrolysates/peptides from various food sources (92). Enzymes are employed in diverse ways to facilitate protein extraction from food, such as cell wall degradation, starch-bond protein release, and protein solubility improvement (93). In this regard, Wang et al. (94) utilized phytase and xylanase to isolate protein from rice bran and noticed that the use of carbohydrates could be helpful to improve the yield of soluble protein.

\section{Physical Methods}

Physical methods are often favored over chemical or enzymatic treatments for food production because they have fewer changes (95). These techniques are more economical and easy to adapt and use in the industry. Conventional physical procedures, such as colloidal milling, homogenization, high-speed blending, freeze-thaw, and high pressure, have been utilized for protein extraction (90).

\section{Microwave-Assisted Extraction}

Microwave heating is a novel technology based on electromagnetic waves with wavelengths and frequencies ranging from $1 \mathrm{~mm}$ to $1 \mathrm{~m}$ and $300 \mathrm{MHz}$ to $300 \mathrm{GHz}$, respectively. It has gained popularity in the food processing industry because of its uniform heating, high heating rates, safety, simple, quick, and clean operation, and low maintenance. Furthermore, this kind of heating has a lower impact on food products' flavor and nutritional quality than conventional heating. By shattering disulfide and hydrogen bonds (non-covalent bonds), this approach can cause protein unfolding, which affects the secondary and tertiary structures of proteins $(96,97)$. In this respect, the microwave process was shown to assist the chia seed protein enzymatic hydrolysis with enhanced bioactivity (antioxidant activity), and functionality (emulsification and foaming properties) gained in a shorter time in comparison to traditional hydrolysis techniques (98).

\section{Ultrasound-Assisted Extraction}

Sonication is a green, novel, innovative and sustainable strategy based on high sound waves of frequencies $(>16 \mathrm{kHz})$ undetectable by the human ear. This approach has several benefits compared with traditional thermal processes, including higher efficiency, higher rate, more accessible and cheaper application and operation, lower equipment contamination, and higher quality and functionality of processed foods $(98,99)$. In this context, Zhao et al. (100) demonstrated that sonication with power levels of 200,400 , or $600 \mathrm{~W}$ for 15 or 30 min altered the secondary and tertiary structure of walnut protein isolate without any impact on its primary structure since the process could not break the covalent bonds. Further, Vanga et al. (101) indicated that ultrasonic treatment $(25 \mathrm{kHz}, 400 \mathrm{~W}, 1-16 \mathrm{~min})$ reduced soymilk protein trypsin inhibitor activity by $52 \%$ and enhanced its digestibility.

\section{Ohmic Heating}

Ohmic heating is a thermal processing technology that applies alternating electric currents directly into a semi-conductive media. It was initially employed for milk pasteurization in 1920. According to Joule's law, direct or volumetric heat is generated in products by passing a moderate and alternating electric current through them, which functions as resistance in an electrical circuit $(102,103)$. In this way, Li et al. (104) evaluated the structure and techno-functionality of proteins in soybean milk when using ohmic heating against traditional heating. Their findings revealed that ohmic heating effectively reduced heating time and enhanced the protein's emulsifying capacity. 
TABLE 1 | Peptides from milk and by-products and their bioactivity.

\begin{tabular}{|c|c|c|c|}
\hline Source & Peptide sequence & Bioactivity & References \\
\hline \multirow[t]{2}{*}{ Bovine milk } & Lys-Val-Leu-Pro-Val-P(Glu) & Antihypertensive activity & $(10)$ \\
\hline & $\mathrm{N} / \mathrm{A}$ & Antimicrobial activity & $(11)$ \\
\hline \multirow[t]{2}{*}{ Cheddar cheeses } & $\mathrm{N} / \mathrm{A}$ & Antimicrobial, antioxidant, and antihypertensive activity & $(12)$ \\
\hline & $\mathrm{N} / \mathrm{A}$ & Phosphopeptides & $(13)$ \\
\hline Casein hydrolysates & Arg-Tyr-Lue-Gly-Tyr & Antihypertensive activity & $(14)$ \\
\hline Comte cheese & $\mathrm{N} / \mathrm{A}$ & Phosphopeptides & $(15)$ \\
\hline Feta, Swiss cheeses & $\mathrm{N} / \mathrm{A}$ & Antiamnesic & $(16)$ \\
\hline Mik fermented & $\begin{array}{l}\text { lle-Pro-Pro } \\
\text { Val-Pro-Pro }\end{array}$ & ACE-inhibitory activity & $(17)$ \\
\hline Enzyme modified cheese & $\mathrm{N} / \mathrm{A}$ & Opioid activity and ACE-inhibitory activity & $(18)$ \\
\hline \multirow[t]{4}{*}{ Yogurt } & $\mathrm{N} / \mathrm{A}$ & Antihypertensive and antimicrobial activity & (19) \\
\hline & к-casein: Met-Ala-Ile & Antithrombotic activity & $(20)$ \\
\hline & $\mathrm{N} / \mathrm{A}$ & Immunomodulatory & (13) \\
\hline & $\mathrm{N} / \mathrm{A}$ & Antithrombotic & $(21)$ \\
\hline \multirow[t]{2}{*}{$\beta$ - lactoglobulin } & $\beta$-lactosin B & Antihypertensive activity & $(22)$ \\
\hline & & Antithrombotic activity & (23) \\
\hline Fermented milk & Val-Pro-Pro,lle-Pro-Pro & Antihypertensive activity & $(24)$ \\
\hline \multirow[t]{2}{*}{ Sour milk } & $\mathrm{N} / \mathrm{A}$ & Phosphopeptides & $(25)$ \\
\hline & $\mathrm{N} / \mathrm{A}$ & Antihypertensive properties & $(16)$ \\
\hline \multicolumn{4}{|l|}{ By-products } \\
\hline \multirow[t]{3}{*}{ Whey protein hydrolysate } & Lactoferricin & Antimicrobial activity, anti-cancer & $(24)$ \\
\hline & N/A & Opioid activity & $(26)$ \\
\hline & $\begin{array}{l}\text { TTFHTSGY } \\
\text { GYDTQAIVQ }\end{array}$ & Antihypertensive properties & (13) \\
\hline Whey proteins & N/A & Anticancer & (15) \\
\hline
\end{tabular}

N/A, Not available.

The protein's foaming ability, on the other hand, reduced as its surface hydrophobicity dropped.

\section{The Pulsed-Electric Field (PEF)}

The pulsed-electric field (PEF) technique has been employed as a non-thermal process for microorganisms and enzymes inactivation. In this technology, the food sample is subjected to short high-power electrical pulses ( $\mu$ s or ms) between electrodes (105). A PEF system consists of a chamber, electrodes, a highvoltage pulse generator, and a computer for monitoring and controlling devices. A strong electric field is formed between two electrodes because of their electrical potential difference. During the PEF process, the generated electrical energy might cause protein unfolding and enhanced interactions with the solute. This can impact the peptides/protein's functional characteristics by increasing its solubility (106). In this regard, PEF treatment of canola seeds enhanced the extracted protein's solubility, emulsifying, and foaming capabilities, according to Zhang et al. (107). Nevertheless, depending on the strength and duration of the PEF process, it can result in denaturation and aggregation, resulting in decreased solubility. The PEF method can change plant-derived peptides and proteins' secondary and tertiary structures. Changes in the secondary structure of peptides derived from pine nut protein were also informed, along with their antioxidant effect (108).

\section{Purification and Identification of Bioactive Compounds}

All the methods for purifying and identifying bioactive peptides are very similar. Purification of active peptides is required to produce a commercially viable product. Ultrafiltration, RP-HPLC, size exclusion chromatography, and ion-exchange chromatography, can all be used to purify bioactive peptides. Additionally, for protein identification, analytical techniques such as mass spectrometry (MS), electrospray ionization MS, matrix-assisted laser desorption ionization time-of-flight MS, liquid chromatography-MS/MS, and hydrophilic interaction liquid chromatography (HILIC) are widely utilized (109).

\section{BIOACTIVITIES OF BIOACTIVE PEPTIDES AND THEIR IMPACT ON HEALTH}

Proteins are necessary for the growth and the preservation of many biological processes. The awareness regarding physiologically active peptides is growing quickly, as they may serve as possible modifiers for several regulative functions in the body. Bioactive peptides have different biological actions depending on the amino acid class, net charge, secondary structures, sequence, and molecular mass (110). Multiple studies have determined the bioactivities of peptides, which were linked 
TABLE 2 | Peptides from meat and by-products and their bioactivity.

\begin{tabular}{|c|c|c|c|}
\hline Source & Peptide sequence & Bioactivity & References \\
\hline Duck breast meat & $\begin{array}{l}\text { LQAEVEELRAALE } \\
\text { IEDPFDQDDWGAWKK }\end{array}$ & Antioxidant activity & $(27)$ \\
\hline Beef muscle & DFHING & Antihypertensive activity & $(28)$ \\
\hline Bovine brain & MPPPLPARVDFSLAGALN & Phosphoenolpyruvate inhibitory activity & $(29)$ \\
\hline Venison muscle & $\begin{array}{l}\text { MQIFVKTLTG } \\
\text { DLSDGEQGVL }\end{array}$ & Antioxidant activity & $(30)$ \\
\hline Beef muscle & GFHI, DFHING, FHG, GLSDGEWQ & Antimicrobial activity & $(28)$ \\
\hline Fermented meat sauce & GYP & Antioxidant activity & $(31)$ \\
\hline Chicken breast protein & Breast protein hydrolysate & Antioxidant activity & $(32)$ \\
\hline Bovine muscle & YEDCTDCGN & Anti-opioid activity and ACE-inhibitory activity & (29) \\
\hline \multicolumn{4}{|l|}{ By-products } \\
\hline Duck skin & $\mathrm{N} / \mathrm{A}$ & Antioxidant activity & (33) \\
\hline Bovine myoglobin & AKHPSDFGADAQA & & (34) \\
\hline Bovine blood & YPWT & Opioid activity & (29) \\
\hline Bovine blood & $\begin{array}{l}\text { TKAVEHLDDLPGALSELSDLHAHKLR } \\
\text { VDPVNFKLLSHSLL }\end{array}$ & Antihypertensive activity & (35) \\
\hline Bovine tendon & $\begin{array}{l}\text { AKGANGAPGIAGAPGFPG } \\
\text { ARGPSGPQGPSGPP }\end{array}$ & & $(36)$ \\
\hline Bovine blood & STVLTSKYR & Antimicrobial activity & $(37)$ \\
\hline Buffalo horn & AADNANELFPPN & Antioxidant activity & (38) \\
\hline Bovine skin & $\mathrm{N} / \mathrm{A}$ & & (39) \\
\hline Bovine brain & $\mathrm{N} / \mathrm{A}$ & & $(40)$ \\
\hline Buffalo horn & AADNANELFPPN & & (38) \\
\hline Yak skin & $<3 \mathrm{kDa}$ & & $(41)$ \\
\hline Sheep abomasum protein & LEDGLK & & $(42)$ \\
\hline Bovine liver & $<10 \mathrm{kDa}$ & & $(43)$ \\
\hline Dry-cured ham bones & N/A & & $(44)$ \\
\hline Chicken liver & N/A & & $(45)$ \\
\hline Chicken bone collagen hydrolysates & N/A & Lipid-lowering activity & $(46)$ \\
\hline
\end{tabular}

N/A, Not available.

to improved overall health and a lower risk of specific chronic diseases, such as cancer, diabetes, and heart diseases (Figure 2).

\section{Antioxidant Activity}

Reactive oxygen species cause cell damage, leading to cancer, diabetes, cardiovascular disease, and hypertension (111). The antioxidative characteristics of bioactive peptides are associated with their composition, formation, and hydrophobicity. Histidine, glutamic acid, proline, tyrosine, cysteine, methionine, and phenylalanine are all amino acids with antioxidant properties (112). Amino acids bind pro-oxidant metal ions to perform their activity, scavenge the $\mathrm{OH}$ radical and/or inhibit lipid peroxidation. As a result, each amino acid contributes as an antioxidant uniquely, depending on its type (67). Most antioxidant peptides include $4-16$ amino acid residues and have a molecular mass of $0.4-2 \mathrm{kDa}$. Peptide molecular size influences both the pathways to target locations and the gastrointestinal digesting process, potentially increasing antioxidant activity in vivo (113). Tyrosine-containing peptides work primarily through hydrogen atom transfer, whereas cysteine, tryptophan, and histidine-containing peptides work mainly through single electron transfer (114). Aromatic amino acids like Tyr and Phe are excellent at donating protons to electron-deficient radicals. This characteristic enhances the bioactive peptides' radicalscavenging abilities. The antioxidant capacity of His-containing peptides is confirmed to be linked to hydrogen donating and lipid peroxyl radical trapping (115). The sulfhydryl group in cysteines, on the other hand, is endowed with an antioxidant effect because of its primary reaction with radicals (116). Plantbased proteins derived from industrial food and its by-products, such as soybean, wheat germ, hemp seeds, rice bran, sesame bran, wheat bran, and rapeseed, possess bioactive peptides with antioxidant characteristics (117).

\section{Antimicrobial Activity}

Antimicrobial peptides possess an antimicrobial activity that protects mammals from various bacteria, fungi, and viruses. Antimicrobial activity is also a coveted feature in prepared foods since it directly impacts the product's shelf life. Antimicrobial peptides are divided into three categories: short (20-46 amino acid residues), basic (rich in Lys or Are), and amphipathic. They are commonly abundant in hydrophobic residues, such 
TABLE 3 | Peptides from plants and by-products and their bioactivity.

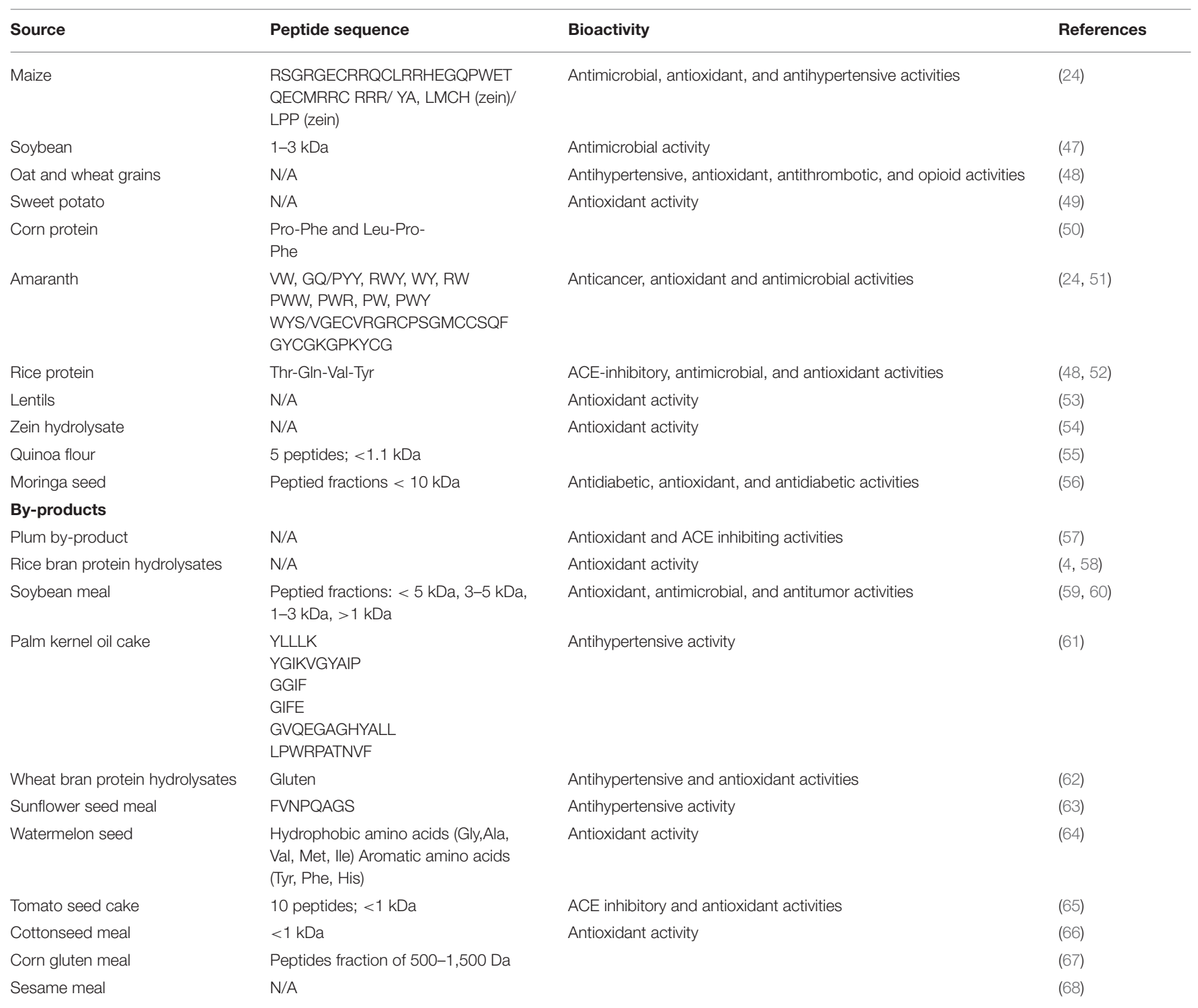

N/A, Not available.

as Leu, Ile, Val, Phe, and Try (118). Multicellular organisms create antimicrobial peptides as defensive strategies against pathogenic microorganisms. Antimicrobial peptides can alter the cell membrane and biological processes, including cell division (119). Their action is assumed to create channels or pores within bacterial membranes, inhibiting anabolic activities, changes in gene expression and signaling transduction, and promoting angiogenesis. For example, the antimicrobial action of milk is demonstrated by extensive research. Lactoferrin, which is hydrolyzed into lactoferricin in the gastrointestinal tract, is an essential contributor to the synthesis of various other bioactive peptides and has antimicrobial ability in and of itself (120). Antimicrobial peptides have also been discovered in marine products. Many microorganisms, like Staphylococcus aureus, Escherichia coli, Bacillus subtilis, Shigella dysenteriae, Pseudomonas aeruginosa, Salmonella typhimurium, and Streptococcus pneumoniae, were inhibited by the peptide GLSRLFTALK, isolated from anchovy cooking wastewater (121). Moreover, Aguilar-Toalá et al. (122) found that adding chia protein hydrolysate $(<3 \mathrm{kDa})$ possessed higher antimicrobial activity than both chia peptide fraction 3-10 kDa. Furthermore, the $<3 \mathrm{kDa}$ fraction demonstrated a notable increase in membrane permeability of E. coli (71.49\% crystal violet uptake) and L. monocytogenes ( $80.10 \%$ crystal violet uptake).

\section{Mineral Binding}

At intestinal $\mathrm{pH}$, peptides with specific sequences create compounds by binding in solution with minerals, such as calcium ( $\mathrm{Ca}$ ) and phosphorus (P). As these peptides have a higher anionic character, they form soluble complexes 
TABLE 4 | Peptides from marine and by-products and their bioactivity.

\begin{tabular}{|c|c|c|c|}
\hline Source & & Bioactivity & References \\
\hline Shrimp proteins & $\mathrm{N} / \mathrm{A}$ & Antihypertensive activity & (69) \\
\hline Tuna proteins & $\mathrm{N} / \mathrm{A}$ & & $(70)$ \\
\hline Sea cucumber hydrolysate & & & $(71)$ \\
\hline Conger eel protein & LGLNGDDVN & Antioxidant activity & $(72)$ \\
\hline Sardine protein & LQPGQGQQ & & (73) \\
\hline Mackerel filet protein hydrolysate & $\mathrm{N} / \mathrm{A}$ & & $(74)$ \\
\hline Royal jelly protein & 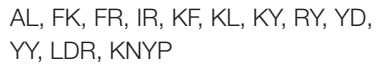 & & (75) \\
\hline Mollusks (Conus magus) & $\mathrm{N} / \mathrm{A}$ & Analgesic & $(24)$ \\
\hline Seaweed (Eucheuma serra) & Lectins & Anticancer & (76) \\
\hline Sponges (Jaspis spp.) & Jaspamide & & $(77)$ \\
\hline Geodia corticostylifera & $\mathrm{N} / \mathrm{A}$ & Antiproliferative & (78) \\
\hline \multicolumn{4}{|l|}{ By-products } \\
\hline Tilapia (O. niloticus) skin & Leu-Ser-Gly-Tyr-Gly-Pro & Antihypertensive activity & Chen et al. (79) \\
\hline Pacific cod skin gelatin & N/A & & (80) \\
\hline Tuna backbone & VKAGFAWTANQQLS & Antioxidant activity & $(81)$ \\
\hline Hoki skin gelatin & HGPLGPL & & $(82)$ \\
\hline Salmon (Protamine, derived from fish milt) & Pro-Arg (271.3 Da) & & (83) \\
\hline Horse mackerel viscera & Ala-Cys-Phe-Leu & & $(84)$ \\
\hline Olive flounder ( $P$. olivaceus) surimi & $\mathrm{N} / \mathrm{A}$ & Antihypertensive activity & (85) \\
\hline Bluefin leatherjacket heads & $\begin{array}{l}\text { Trp-Glu-Gly-ProLys; } \\
\text { Gly-Pro-Pro; } \\
\text { Gly-Val-Pro-Leu-Thr }\end{array}$ & Antioxidant activity & $(86)$ \\
\hline
\end{tabular}

N/A, Not available.

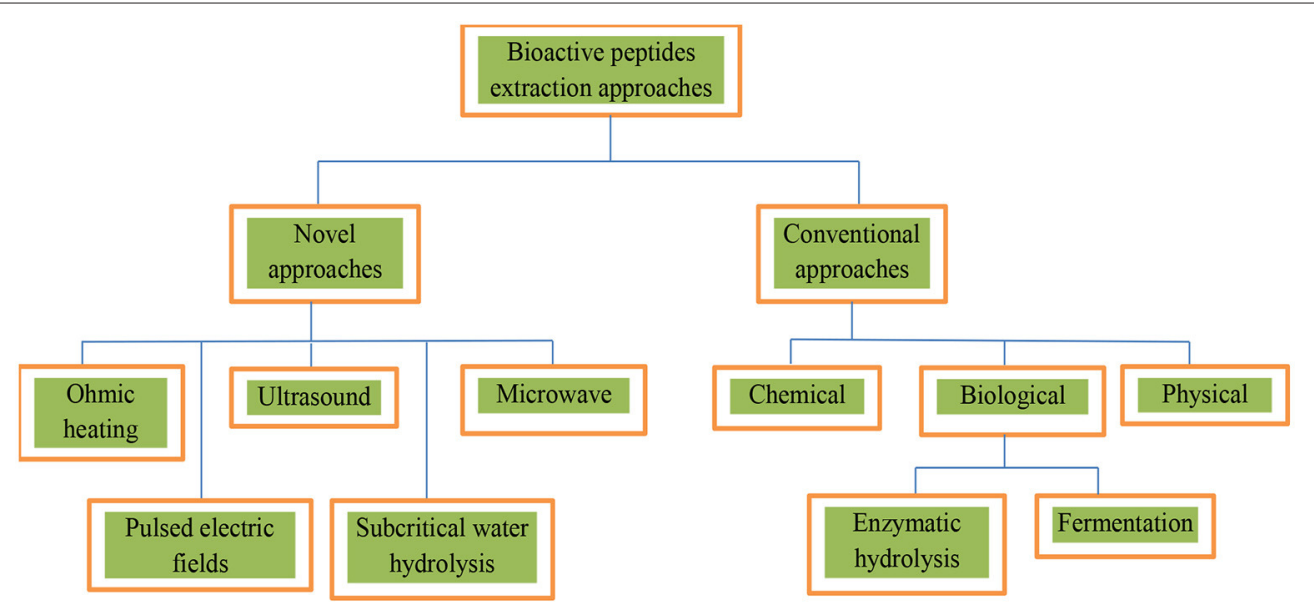

FIGURE 1 | Scheme for extracting bioactive peptides.

immune to additional proteolytic attacks, blocking the creation of insoluble mineral compounds (24). Flaxseed proteins contain hydrophobic and positively charged amino acids that might aid enzymatic hydrolysis in generating calmodulin (CaM)-binding peptides. Flaxseed proteins were digested with alcalase to produce low-MW peptides (123). Milk caseins are also known to bind $\mathrm{Ca}$ and $\mathrm{P}$ ions, increasing their bioavailability (24).

\section{Opioid Activity}

Opioid peptides are naturally synthesized and have analgesic properties (124). They bind to the opiate receptor and exhibit opiate-like actions suppressed by naloxone (125), with a specific impact on the neurological system (126). Prodynorphin (dynorphins), proopiomelanocortin (endorphins), and proenkephalin (enkephalin) are the three types of precursor proteins found in typical opioid peptides (127). The N-terminal 


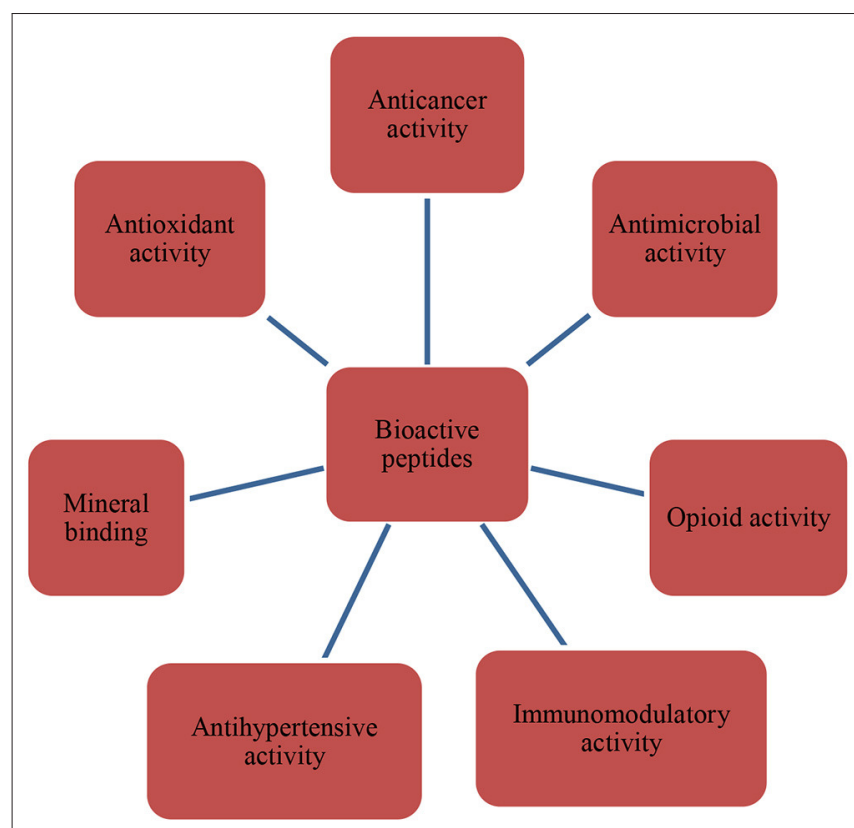

FIGURE 2 | Bioactivities of bioactive peptides.

sequences Tyr-Gly-Gly-Phe and Tyr-Pro are prevalent in these peptides (113). Opioid peptides can be found in milk and dairy products (18) and various plant sources, including oats, wheat, rye, barley, and maize (128). Pihlanto-Leppälä (129) found that opioid peptides interact with particular receptors on target cells.

\section{Anticancer Activity}

Cancer has become one of the world's most feared and deadly diseases. Pharmaceutical companies are developing anticancer and antitumor medications at a rapid pace. Further, oncology research is well-progressed and has improved our understanding of tumors over time (130). Food protein hydrolysate is an excellent foundation for the generation of anticancer peptides. The anticancer effect of rice and soy protein hydrolysates has been previously demonstrated. In rice, anticancer peptides are produced by alcalase digestion of rice bran proteins (131). Another anticancer peptide (Ala-Phe-Asn-Ile-His-AsnArg-Asn-Leu-Leu) was separated from shellfish proteins, which successfully killed breast, prostate, and lung cancer cells while leaving normal liver cells unharmed (132). Most anticancer investigations on peptides are conducted on lunasin; a peptide derived from soy or wheat grains (24). The anticancer properties of lunasin are linked to its particular amino acid sequences, which contain Arg-Gly-Asp for cell adhesion and a polyaspartic acid chain with nine aspartic acid residues (133). Fermented soybean extracts impact the proliferation of MCF7 breast cancer cells and downregulate gene expression, according to Hwang et al. (134). The investigators found that, through stimulating the TGF pathway, fermented soybean extracts may effectively prevent breast cancer. According to Badger et al. (135), soy peptide concentrates reduce the incidence of breast, prostate, and gastrointestinal cancers. They claimed that soy peptide concentrates could reduce cancer incidence by $80 \%$. Further, peptides from black soybean, mung bean meal, and adzuki bean were found to suppress cancer cells at 200-600 g/mL concentrations (136). These anticancer peptides were only studied in vitro; further investigation on their bioavailability is needed.

\section{Antihypertensive Activity}

Owing to the changes in lifestyle in modern society, there is a growing need for functional foods with blood-pressurelowering benefits in the therapy of hypertension. Hypertension can cause multiple disorders, including heart and renal diseases, arteriosclerosis, and stroke (137). Antihypertensive peptides (also known as angiotensin-converting enzyme (ACE) inhibitors) generated by protein hydrolysates are the most studied peptides (138). In this respect, ACE has a crucial effect since it catalyzes the transformation of angiotensin I to angiotensin II, which leads to a rise in blood pressure. Aromatic amino acid residues at the $\mathrm{C}$-terminus and hydrophobic amino acid residues at the $\mathrm{N}$-terminus help peptides block ACE function more effectively (139). Various plant sources, including pea (Ile-Arg, Lys-Phe, and Glu-Phe), soybean (Asp-Leu-Pro and Asp-Gly), and rice (Ile-His-Arg-Phe), have been shown to possess active peptides with antihypertensive capacity (117). Marambe et al. (140) found that defatted flaxseed protein hydrolysate reduced the ACE activity, lowering the risk of cardiovascular disorders. Many tripeptides that restrain ACE have been separated from foods. In this context, Wang et al. (141) confirmed that an active peptide (Tyr-Ser-Lys) derived from rice bran had a potent ACE inhibitory effect. Another work by Tuomilehto et al. (17) found that the milk-obtained bioactive tripeptides (Val-ProPro and Ile-Pro-Pro) lowered blood pressure in moderately hypertensive patients. Bioactive peptides, particularly those with low molecular weight, inhibited ACE, decreased blood pressure and prevented hypertension.

\section{Immunomodulatory Activity}

Immunomodulatory activity is essential for the human immune system to function correctly. The immunomodulatory effect of bioactive peptides depends on cytokine regulation, antibody formation, immune system stimulation via reactive oxygen species, conformational changes in tubulin, and inhibition of protein synthesis (87). Furthermore, the amino acid content, sequence, length, charge, hydrophobicity, and peptide structure are linked to the immunomodulatory function. In this regard, soy protein hydrolysates with low molecular weight and many positively charged peptides have been proven to stimulate immunomodulation (142). Numerous plant-generated bioactive peptides with immunomodulatory action, including Leu-Asp-Ala-Val-Asn-Arg and Met-Met-Leu-Asp-Phe, possess low molecular weights (686 and $655 \mathrm{Da}$, respectively) and hydrophobic characteristics (143). According to Ngo et al. (144), marine products are a significant source of bioactive peptides that have been used as a treatment for a variety of disorders. 


\section{Anti-inflammatory Activity}

Anti-inflammatory effects have been found in proteins/peptides derived from eggs, milk, and plants (145). The anti-inflammatory characteristics of new active peptides from sponges, bacteria, and microalgae have been documented, along with the molecular diversity of marine peptides and data regarding their antiinflammatory impact and modes of action (146). Zhao et al. (147) reported that anti-inflammatory peptides generated from velvet antler simulated gastrointestinal digests were purified and identified using LC-MS/MS. Four anti-inflammatory peptides were identified, namely $\mathrm{VH}, \mathrm{LAN}, \mathrm{AL}$, and IA. These findings proposed that peptides obtained from velvet antler protein might be a viable anti-inflammatory agent in functional ingredients. Bioactive peptides promoted diet-induced hepatic fat deposition and hepatocyte pro-inflammatory response when evaluated on SAMP8 aging rats (148). In vitro and in vivo investigations have revealed that corn, whey, and soybean protein hydrolysates have a powerful anti-inflammatory effect $(149,150)$.

\section{APPLICATIONS OF BIOACTIVE PEPTIDES}

\section{Food Applications}

Bioactive peptides have shown to be extremely useful in developing numerous health-oriented functional diets. These peptides are used as sweeteners, color stabilizers, thickeners, anti-caking factors, emulsifiers, flavor enhancers, emulsifiers in food preparation, and acidity control. Bioactive peptides may also improve food quality by affecting the water and oil retention capacity, colloidal stability, viscosity, and foam generation in the finished product (151). Peptide isolates used in the formulation of functional products aid in creating certain required technical qualities. Numerous studies have been conducted on proteins/peptides of different origins to produce functional foods. Emulsification is a necessary procedure that is frequently utilized to assess protein-rich products. Due to their amphiphilic character, bioactive peptides derived from food byproducts are important for emulsifying attributes (152). Active peptides derived from plant sources like potato (153), flaxseed (154), and soybean (155) have been found to exhibit emulsifying capabilities. As reported by Álvarez et al. (156), adding rice bran protein concentrate to beef products increased its emulsion stability and rheological qualities. Due to the increased levels of bioactive peptides, Talukder and Sharma (157) found that using oat bran concentrate in the formulation of chicken meat patties resulted in better emulsion activity than that obtained using wheat bran concentrate. Likewise, Kamani et al. (158) observed that soy protein concentrate and gluten in sausage recipes increased emulsion stability and gel-forming capabilities by producing a robust structural network.

Foam formation can generate acceptable textural and sensory characteristics in food such as pastries and sauces (159). Their capacity to reduce surface tension facilitates the use of active peptides as foam stabilizers. Rice bran protein isolates had a comparable foaming potential to egg white but much lower foaming stability (114). Similarly, Elsohemy et al. (160) reported that the foaming capacity of the quinoa seed protein concentrate was much higher than that of soybean cake protein concentrate.
According to Kamani et al. (158), soy protein concentrate minimizes the cooking/frying loss and shrinkage and enhances foaming stability in chicken sausages.

Various trials have evaluated plant protein concentrates in food applications to reduce the oil ratio and improve the end product's industrial attributes. Plant-based protein hydrolysates have been given significant attention, particularly for enhancing the water-holding ability of meat products (161), which plays a critical role in defining their juiciness, an expression that also refers to the flavor, texture, and color required throughout technological operations (162). In this regard, Carvalho et al. (163) stated that soy protein concentrate employed in beef burger formulation significantly improved the patties' waterholding capacity. Additionally, Hidayat et al. (162) found that this capacity ranged from 86 to $89 \%$ in beef sausage and was enhanced by replacing beef with texturized vegetable protein $(0-40 \%)$. This might be attributed to the existence of more water-soluble components than in animal proteins. According to Karami and Akbariadergani (164), canola protein hydrolysates improved the cooking yield by raising the water-retaining capability of the meat product.

Consumers and the food industry are concerned about lipid oxidation, creating unwanted off-flavors, odors, and possibly serious reaction products (165). Suppressing lipid peroxidation in foodstuffs is critical to prevent food deterioration and protect consumers against hazardous diseases. In this regard, antioxidants are utilized to keep food safe by preventing discoloration and the decay caused by oxidation $(166,167)$. Despite the extensive use of synthetic antioxidants in food production, the consumers' concern around food safety prompted the food industry to seek natural alternatives (168, 169). Antioxidant proteins and peptides can replace artificial antioxidants since they have an equivalent or higher ability to suppress lipid oxidation (170). Carnosine ( $\beta$-alanylL-histidine) and glutathione ( $\gamma$-Glu-Cys-Gly) are natural antioxidants in muscle tissue. It has been discovered that they can scavenge hydroxyl radicals, quench singlet oxygen, and restrain lipid oxidation (171). The peptide Pro-Ala-Gly-Tyr separated from Amur sturgeon skin gelatin has scavenging abilities against DPPH, ABTS, and hydroxyl radicals, according to Nikoo et al. (172). The peptide reduced lipid oxidation in minced fish at a concentration of $25 \mathrm{ppm}$, but it was ineffective at greater concentrations. According to Shahidi et al. (173), incorporation of capelin protein hydrolysate at $0.5-3.0 \%$ in a beef model decreased the generation of TBARS by $17.7-60.4 \%$. Over 14 days of storage at $4^{\circ} \mathrm{C}$, Kittiphattanabawon et al. (174) assessed lipid peroxidation in treated pork containing gelatin hydrolysate of $40 \% \mathrm{DH}$, at concentrations of 100, 500, and 1,000 ppm, and BHA (100 ppm). In both the carotene linoleate and treated pork model systems, they found that gelatin hydrolysate at 500 and 1,000 ppm inhibited lipid peroxidation. Bougatef et al. (175) isolated and purified antioxidant peptides from Sardinella aurita proteins by enzymatic hydrolysis. These peptides were found to have a high antioxidant potential in meat-based products. Furthermore, the antioxidant activity of peptides isolated from the mushroom Ganoderma lucidum was discovered to reduce lipid oxidation without altering the 
products' consumer desirability qualities. The antioxidant activity of G. lucidum was attributed to the polysaccharidepeptide complex, polysaccharides, and phenolics. Nevertheless, the study found that G. lucidum peptide (GLP) is the main antioxidant in G. lucidum, which may effectively reduce lipid peroxidation in meat goods by scavenging free radicals, chelating metals, and acting as an antioxidant (176). In a linoleic acid model system, gelatin hydrolysates from cobia (Rachycentron canadum) skin delayed lipid oxidation. Cobia gelatin hydrolysate at 8 and $10 \mathrm{mg} / \mathrm{mL}$ exhibited a higher inhibitory effect on lipid peroxidation than BHA at $10 \mathrm{mg} / \mathrm{L}$ (177). In addition, according to Cai et al. (178), peptides gained from grass carp (Ctenopharyngodon idella) skin protein hydrolysate significantly prevented peroxidation in a linoleic acid model system. Sivaraman et al. (179) reported that the squid protein hydrolysate generated by papain has a comparable lipid peroxidation inhibitory capacity as ascorbic acid in the sardine ground meat model system. Similarly, zein hydrolysate has been shown to suppress lipid oxidation, diminish hydrogen peroxide and TBARS generation, and considerably increase the oxidative stability of model oils (180). Furthermore, this hydrolysate shows no adverse effects on emulsion quality and could be used as an effective antioxidant in food emulsion (181). Cuttlefish skin gelatin hydrolysates $(0.5 \mathrm{mg} / \mathrm{g})$ prevented turkey sausage lipid peroxidation for up to 10 days at $4^{\circ} \mathrm{C}$ (182).

Proteins derived from dairy sources are, likewise, high in antioxidant peptides, which could be helpful in the preservation of meat. In this respect, casein calcium peptide $(2.0 \%)$ combined with beef paste homogenate can suppress around $70 \%$ of lipid peroxidation of the homogenate, preventing the formation of odors in meat products and thus, extending their shelf life (183). Additionally, whey protein peptides have also demonstrated their ability to be utilized as functional components in meat goods. Peña-Ramos and Xiong (184) found that adding $2 \%$ whey protein hydrolysates to pig meat in cold storage decreased oxidative deterioration and loss during cooking. From the experience of the authors, there are numerous bioactive peptides available. Nevertheless, adaptability with different foods, gastrointestinal stability, bioavailability, and long-term stability must be investigated before application as functional food additives.

\section{Pharmaceutical Applications}

The use of bioactive peptides for pharmaceutical applications is as interesting as that for food purposes. In this context, bioactive peptides and their by-products have been applied as antidiabetic, anticancer, and anti-inflammatory agents, to name a few. Antidiabetic hydrolysates, for example, can be added to sausages to fortify the sausages with anti-diabetic peptides to reduce the probability of developing diabetes (185). The identity of 24, 30, and 38 bioactive peptides were established in each of three infant milk formulas after separating and identifying bioactive peptides in three hypoallergenic formulas. A large number of these peptides has been identified as ACE inhibitors. The presence of sequences with antihypertensive, hypocholesterolemic, immunomodulation, antibacterial, cytotoxicity, antigenic, antioxidant, and antigenic activities was also established (186).
Chou et al. (45) investigated the impact of antioxidant peptides from the chicken liver after enzyme digestion by pepsin and the induction of CAT, GPx, and SOD in D-galactose-induced rats. Comparing the control and the D-galactose-induced groups of rats, the doses of chicken liver hydrolysate administered (0.25 and $0.5 \mathrm{~g} / \mathrm{kg}$ ) resulted in equal or enhanced antioxidant capacity in the liver, heart, kidney, and brain. The researchers discovered that dosages of 0.25 and $0.5 \mathrm{~g} / \mathrm{kg}$ inhibited the same rate of lipid oxidation in serum and liver as in the control group. Similar findings were also observed by other scientists in terms of the antioxidant potential (in vivo) of loach meat hydrolysates (187), chicken breast hydrolysates (32), rice proteins (188), and tilapia collagen (189). Fazhi et al. (68) reported that three peptides (tri-, tetra-, and hexapeptide) were isolated from fermented sesame meal. They found that MDA buildup in serum and liver was decreased by supplementation with any peptide at $0.1,0.2$, or $0.4 \mathrm{~g} / \mathrm{kg}$. In addition, all treated mice had higher levels of SOD and GPx.

Numerous bioactive peptides from food have been shown to possess cytomodulatory properties. In particular, peptides recovered from waste whey of mozzarella cheese exhibited an antiproliferative action when evaluated in a human colorectal cancer cell line (190). Similarly, cytomodulatory peptides decreased the growth of cancer cells while also increasing the activity of immune and neonatal intestinal cells (191). The cytotoxic effects of several black cumin extracts as an additional remedy to doxorubicin treatment in human MCF-7 breast cancer cells were also investigated in terms of their anticancer activity. The LC50 of black cumin lipid extract was $2.7200 .2 \mathrm{mg} / \mathrm{mL}$, indicating cytotoxicity. The cytotoxicity of the aqueous extract was evident when the level was as high as $50 \mathrm{mg} / \mathrm{mL}$ (192). Furthermore, Saisavoey et al. (193) studied rice bran protein hydrolysate antioxidant and anti-inflammatory properties on the RAW264.7 macrophage cell line, where LPS and rmIFN-g were found to co-stimulate the target protein's inhibitory effect against nitric oxide production. In addition, casein has been discovered to be an abundant source of active opioid peptides. Different casein fragments are hydrolyzed by distinct digestive enzymes, resulting in the formation of peptides with opioid activity (194). These opioid casein fractions were solely discovered in the plasma of newborns, which was surprising. In both animal and human trials, a marketable, valuable 1-casein-derived peptide frequently utilized in confections and soft beverages were shown to have anxiolytic-like stress-relieving characteristics (194).

Plant-based proteins have proven to be a precious source of innovative and effective antihypertensive peptides (113). In this respect, four angiotensin-converting enzyme inhibitory peptides (Val- Trp, Val-Trp-Ile-Ser, Ile-Tyr, and Arg-Ile-Tyr) were identified from rapeseed proteins digested with subtilisin. When orally administered, these peptides were reported to reduce blood pressure in hypertensive rats, with the most significant effect occurring between 2 and 4 h from administration (195). Incorporating these and other antihypertensive peptides into pharmaceutical medicines and functional diets may effectively prevent and treat hypertension. In mammals, antihypertensive peptides also aid in regulating salt balance and fluids (196). Milk-based bioactive peptides might be used to reduce the risk 
of metabolic syndrome by modulating blood pressure, food consumption, and free radical absorption (197).

\section{Cosmeceutical Applications}

Since a scientific demonstration of the stated bioactivity of novel cosmeceutical substances is frequently required, research in the cosmeceutical sector, which combines cosmetics and pharmaceuticals, is continuously growing. Indeed, one feature that distinguishes cosmeceuticals from traditional cosmetics is the discovery and characterization of active substances and the demonstration of their efficacy in the stated activity (198). Peptides are an important collection of bioactive cosmeceutical components that, due to their unique qualities, suit the majority of the cosmeceutical industry's needs when creating new compositions. In this respect, in addition to bioactivity, two other features of peptides as cosmeceutical components have lately been considered: bioavailability and stability. Moreover, peptides are recognized as valuable cosmetic materials, as they are light and air-stable, present low toxicity, show a powerful affinity for water, and possess moisturizing capabilities $(199,200)$. Peptides are frequently employed as ingredients in functional cosmetics to treat skin conditions, promoting collagen synthesis and antioxidant, anti-inflammatory, anti-wrinkle, whitening, and wound healing properties $(201,202)$. Developing new natural peptides and more stable and effective synthetic peptides has sparked renewed interest in peptide-based skincare products (203). Peptides are used as anti-aging skincare due to their ability to synthesize extracellular matrix (ECM) tissue, the disruption of which is key to skin aging (204). Signal, carrier, neurotransmitter inhibitor, and enzyme inhibitor peptides can be categorized as topical cosmeceuticals. Larger molecules can penetrate the skin barrier, particularly in dry and aged skin (205). Synthetic peptides are made up of amino acid chains that may be altered for various purposes, including improved skin penetration, particular receptor binding, stability, and solubility. Finkley and co-authors (206) reported that the facial creams containing GHK-Cu (copper tripeptide 1) applied for 12 weeks on 71 volunteers aged 50-59 resulted in a visible reduction of the signs of aging. In a separate investigation, the same authors tested the formulation on the eyes of 41 pairs of volunteers under comparable experimental conditions, where a cream with vitamin $\mathrm{K}$ was used as a control. The cream with GHK-Cu was found to enhance the suppleness and tightness of the skin in both experiments and lessened the appearance of both fine lines and deep wrinkles. Lintner and Peschard (207) found a significant variation in skin permeability amongst palmitoylated and non-palmitoylated peptides. The anti-wrinkle and wound-healing effects of the peptides palGHK and pal-AH were examined. The transcutaneous flow was disclosed using standard Franz diffusion cells, which showed increased interpenetration in the case of the palmitoylated analog. The collagen-derived pentapeptide KTTKS is another key peptide active component in cosmeceutical formulations (208). In a fascinating clinical investigation, its palmitoylated analog (pal-KTTKS) was tested and compared to the KTTKS peptide regarding stability and permeability. It was discovered that pal-KTTKS could penetrate all three layers of the skin (stratum corneum, epidermis, and dermis), while unmodified KTTKS was not found in any of them (209). According to previous research, collagen may liberate bioactive peptides with various physiological activities after enzymatic digestion. Collagen peptides/hydrolysates have been found to help improve skin problems $(210,211)$. Kang et al. (212) employed hairless mice that had been exposed to UV radiation, which were administered 1,000 mg/kg collagen peptide for 9 weeks. Collagen peptides were found to upregulate the expression of hyaluronic acid synthase mRNA and the skin moisturizing factor filaggrin, boost hyaluronic acid concentration in skin tissue, and downregulate the expression of hyaluronidase (HYAL-1 and HYAL2) mRNA. Likewise, collagen peptide consumption may prevent skin moisture loss caused by ultraviolet (UVB) light (213). Overall, collagen and synthetic peptides have been widely used to develop anti-aging products and nutraceuticals.

\section{Wound Healing Applications}

Human skin wounds continue to be a substantial and growing public health and economic issue (214). The skin is the largest organ of the human body and serves as a physical barrier between the internal and external environments. Undoubtedly, skin wounds occur frequently in unfortunate accidents. When the skin defenses against hazardous stimuli are compromised, adverse outcomes such as infection, shock, and even death can occur $(215,216)$. The wound healing process can be slowed down in specific diseases (e.g., diabetes and infection), usually causing chronic wounds (217). Traditional wound healing medications, such as growth factors, cytokines, chemical compounds extracted or produced from plants, and other immunomodulatory agents, have proven to be especially challenging to translate into clinic treatments for chronic wound healing (218).

Bioactive peptides with high activity, specificity, and stability have sparked substantial interest in the associated field of study (219) compared with expensive pharmaceuticals and low activity, safety, and delivery issues. In this regard, in diabetic$\mathrm{ob} / \mathrm{ob}$ rats (mutant obese rats employed as animal models of type II diabetes), Carretero et al. (220) found that in vivo adenoviral delivery of LL-37 antimicrobial peptides to excisional wounds increased re-epithelialization and granulation tissue formation. Ramos et al. (221) also verified this, finding that LL-37 and PLL-37 (LL-37 derivative containing an N-terminal proline) improve re-epithelialization and angiogenesis in skin lesions with poor wound healing in vitro and in vivo. Song et al. (222) used electrospun silk fibroin nanofiber membranes to immobilize an LL-37 derivative, Cys-KR12. Cys-KR12 was chosen for its antibacterial and anti-biofilm properties vs. four different bacterial strains (S. aureus, S. epidermidis, E. coli, and $P$. aeruginosa) and contained residues 18-29 of the LL-37 sequence. The peptide-modified membranes were discovered to stimulate the proliferation of keratinocytes, fibroblasts, and monocytes, all of which are key to wound healing.

Moreover, collagen peptides serve as fake collagen breakdown peptides in the skin, causing fibroblast cells to create novel collagen fibers in response to a false signal. Collagen peptides also have chemotactic qualities, encouraging cell migration and proliferation, essential to wound healing (223). Recently, 
marine organisms like fish, fish waste, starfish, sponges, and jellyfish have been investigated as reliable sources of collagen (224). Cheng et al. (225) lately discovered that collagen sponges generated from Rhopilema esculentum show potential hemostatic properties, implying that they could be a viable choice for wound treatment. Other biomaterials acquired from marine collagen, such as collagen gels, films, and membranes, have also shown practical applications in wound treatment (226).

\section{Feed Applications}

Enhancing feed utilization efficiency for milk, meat, and egg production is an important goal for animal agriculture. A proper nutrition strategy is required to digest and absorb dietary nutrients in the small intestine. Recently, peptides in animal feeding have received considerable attention $(227,228)$. Before feeding, chemical, enzymatic, or microbiological procedures are utilized to routinely generate peptides from animal and plant proteins to increase the nutritional quality and decrease any associated anti-nutritional effects (229). After consumption, the proteins in the feed are digested in the small intestine by enzymes and oligopeptidases into small peptides (di- and tripeptides) and free amino acids (230). Nonetheless, depending on the physiological state of the animals and the composition of their meals, the types of peptides produced might vary substantially. To produce peptides for animal nutrition, only animal by-products, brewer by-products, and plant materials with anti-nutritional elements are hydrolyzed (231). Different peptide compounds have been added to the meals of calves (232), poultry (233), fish (234), and companion animals (235) to enhance their nutrition, gut function, and capacity to combat infectious diseases. According to Kim (236), fermented soybean meal (4.9\%) might substitute $3.7 \%$ of spray-dried plasma protein in the diet of 3- to-7-week-old pigs given a corn and soybean meal-based diet with no effect on growth performance or feed efficiency. Comparable outcomes were gained for the Atlantic salmon fed a diet including $40 \%$ of protein from fermented soy white flakes (233). In the diet of juvenile red sea bream, $50 \%$ of the fish meal could be substituted with the equivalent quantity of soybean protein hydrolysate (234). As the fish meal is becoming limited worldwide, adding plant-based protein hydrolysate in diets is critical in aquaculture. Moreover, the hydrolysate of soy protein concentrate (19.7\% in diet) can be employed to maintain a sturdy growth in calves as an alternative for expensive skim milk powder (230). In another study, El-Ayek et al. (237) found that black cumin cake can cost-effectively substitute $50 \%$ of the protein in forage formulations. El-Deek et al. (238) reported comparable results, confirming that up to $50 \%$ black seed cake protein may be used in broiler chick feed with no adverse effects on growth, meat quality, feed consumption, conversion rate, or safety.

\section{Safety of Bioactive Peptides}

Bioactive peptide safety is a significant perspective for clinical studies and food applications. The physiological impact of bioactive peptide consumption (from food and hydrolysate/concentrated forms) is thought to be harmless.
Nevertheless, because most toxicological investigations are conducted in vitro and in animals, the level of proof supporting the safety of bioactive intake must be increased. To date, just a few investigations on the potential toxicological impact on humans have been undertaken. In this context, according to an in vitro work conducted by Doorten et al. (239), daily ingestion of a hydrolysate derived from cow milk ( $2 \mathrm{~g} / \mathrm{kg}$ body weight) was not likely to generate mutagenic or clastogenic effects. The scholars found a No Observed Adverse Effect Level (NOAEL) of $40 \mathrm{~g} / \mathrm{kg}$ body weight/day, 140 times greater than the recommended daily intake. Moreover, Anadón et al. (240) found that acute $(2,000 \mathrm{mg} / \mathrm{kg})$ and daily $(1,000 \mathrm{mg} / \mathrm{kg}$ for 4 weeks) ingestion of casein hydrolysate (rich in antihypertensive peptides) neither had any histological impact nor caused mortality in mice. Overall, peptides are more reactive than natural proteins due to their lower molecular weight and are made up of smaller chains of amino acids. As a result, it is critical to ensure their safety, which includes the absence of toxicity, cytotoxicity, and allergenicity (6). Strict and precise legislation is essential to safeguard consumers from potentially hazardous or deceptive products.

\section{Peptide Therapeutics Market}

Therapeutic peptides and proteins have risen as potential drug candidates for several decades. The peptide therapeutics market is moderately competitive and consists of several major parties. Some companies, which are currently overlooking the market, are Eli Lilly and Company, Pfizer, Inc., Amgen, Inc., Bristol-Myers Squibb Company, EVER NEURO PHARMA GMBH, Takeda Pharmaceutical Company Limited, Davisco Foods International, Tokiwa Yakuhin Co., Ltd., Reliv, Inc., Valio Ltd., and many others. The major partakers are involved in strategic alliances, such as acquisitions and collaborations, along with research activities for the global expansion of the product portfolio. For example, in June 2019, Eli Lilly and Company received the FDA approval for Emgality, a subcutaneously injected calcitonin gene-related peptide (CGRP) antibody, for migraine prevention and treating episodic cluster headache ${ }^{1}$.

\section{CONCLUSION AND FUTURE PERSPECTIVES}

The advantages and activities of bioactive peptides derived from various sources were addressed in this review. Peptide extraction, purification, and identification were also covered. Bioactive proteins can be utilized to develop functional foods and are likely to be employed as a food additive in fatty products to extend their shelf life by increasing oxidative stability. New bioactive peptides derived from various food sources and their by-products for food, pharmaceutical, cosmetic, wound healing, feed, and safety were also discussed. Even though much is known about the structure and activity of peptides, more research into the link between these two aspects is required. Further

\footnotetext{
${ }^{1}$ https://www.researchandmarkets.com/reports/5265155/peptidetherapeuticsmarket-growth-trends. Last access: Dec 19, 2021.
} 
investigation is needed on the stability of peptide activity and its regulatory factors, in addition to the extraction of bioactive peptides and qualification of prospective bioactivity. In addition, pre-clinical and clinical studies are needed to determine which levels are beneficial for health, their dose-response relation, bioavailability, pharmacokinetics, and whether they can be consumed with foods.

\section{REFERENCES}

1. Wang N, Manabe Y, Sugawara T, Paul NA, Zhao J. Identification and biological activities of carotenoids from the freshwater alga Oedogonium intermedium. Food Chem. (2018) 242:24755. doi: 10.1016/j.foodchem.2017.09.075

2. Szymanowska U, Baraniak B. Antioxidant and potentially anti-inflammatory activity of anthocyanin fractions from pomace obtained from enzymatically treated raspberries. Antioxidants. (2019) 8:299. doi: 10.3390/antiox8080299

3. Dziki D, Gawlik-Dziki U, Biernacka B. Cistus incanus L. as an innovative functional. Foods. (2019) 8:1-12. doi: 10.3390/foods8080349

4. Zaky AA, Chen Z, Liu Y, Li S, Jia Y. Preparation and assessment of bioactive extracts having antioxidant activity from rice bran protein hydrolysates. $J$ Food Measur Character. (2019) 13:2542-8. doi: 10.1007/s11694-019-00174-9

5. Zaky AA, Liu Y, Han P, Chen Z, Jia Y. Effect of pepsin-trypsin in vitro gastrointestinal digestion on the antioxidant capacities of ultra-filtrated rice bran protein hydrolysates (molecular weight $>10 \mathrm{kDa} ; 3-10 \mathrm{kDa}$, and $<3 \mathrm{kDa}$ ). Int J Pept Res Ther. (2020) 26:1661-7. doi: 10.1007/s10989-019-09977-2

6. Korhonen H, Pihlanto A. Bioactive peptides: production and functionality. Int Dairy J. (2006) 16:945-60. doi: 10.1016/j.idairyj.2005.10.012

7. Ulug SK, Jahandideh F, Wu J. Novel technologies for the production of bioactive peptides. Trends Food Sci Technol. (2021) 108:27-39. doi: 10.1016/j.tifs.2020.12.002

8. Chakrabarti S, Jahandideh F, Wu J. Food-derived bioactive peptides on inflammation and oxidative stress. BioMed Res Int. (2014) 2014:111. doi: $10.1155 / 2014 / 608979$

9. Unal G, Akalin AS. Antioxidant and angiotensin-converting enzyme inhibitory activity of yoghurt fortified with sodium calcium caseinate or whey protein concentrate. Dairy Sci Technol. (2012) 92:627-39. doi: 10.1007/s13594-012-0082-5

10. Mohanty D, Jena R, Choudhury PK, Pattnaik R, Mohapatra S, Saini MR. Milk derived antimicrobial bioactive peptides: a review. Int J Food Prop. (2016) 19:837-46. doi: 10.1080/10942912.2015.1048356

11. Wakabayashi H, Takase M, Tomita M. Lactoferricin derived from milk protein lactoferrin. Curr Pharm Des. (2003) 9:127787. doi: 10.2174/1381612033454829

12. Pritchard SR, Phillips M, Kailasapathy K. Identification of bioactive peptides in commercial Cheddar cheese. Food Res Int. (2010) 43:15458. doi: 10.1016/j.foodres.2010.03.007

13. Meisel H. Biochemical properties of peptides encrypted in bovine milk proteins. Curr Med Chem. (2005) 12:190519. doi: 10.2174/0929867054546618

14. Contreras MDM, Carrón R, Montero MJ, Ramos M, Recio I. Novel caseinderived peptides with antihypertensive activity. Int Dairy J. (2009) 19:56673. doi: 10.1016/j.idairyj.2009.05.004

15. Choi J, Sabikhi L, Hassan A, Anand S. Bioactive peptides in dairy products. Int J Dairy Technol. (2012) 65:1-12. doi: 10.1111/j.1471-0307.2011. 00725.x

16. FitzGerald RJ, Murray BA, Walsh DJ. Hypotensive peptides from milk proteins. J Nutr. (2004) 134:980S-8S. doi: 10.1093/jn/134.4.980S

17. Tuomilehto J, Lindström J, Hyyrynen J, Korpela R, Karhunen ML, Mikkola L, et al. Effect of ingesting sour milk fermented using Lactobacillus helveticus bacteria producing tripeptides on blood pressure in subjects with mild hypertension. J Hum Hypertens. (2004) 18:795802. doi: $10.1038 /$ sj.jhh. 1001745

18. Haque E, Chand R, Kapila S. Biofunctional properties of bioactive peptides of milk origin. Food Rev Int. (2008) 25:28-43. doi: 10.1080/87559120802458198

\section{AUTHOR CONTRIBUTIONS}

$\mathrm{AZ}$ and $\mathrm{AA}$ contributed significantly to analysis and manuscript preparation. AZ supported valuable discussion. JS-G, J-BE, and J-HS revised the whole manuscript. All authors collated papers, wrote the manuscript, read, and approved the final manuscript.

19. López-Expósito I, Gómez-Ruiz JÁ, Amigo L, Recio I. Identification of antibacterial peptides from ovine $\alpha$ s2-casein. Int Dairy J. (2006) 16:107280. doi: 10.1016/j.idairyj.2005.10.006

20. Manso MA, López-Fandiño R. Angiotensin I converting enzymeinhibitory activity of bovine, ovine, and caprine $\kappa$-casein macropeptides and their tryptic hydrolysates. J Food Protect. (2003) 66:1686-92. doi: 10.4315/0362-028X-66.9.1686

21. Fitzgerald RJ, Murray BA. Bioactive peptides and lactic fermentations. Int $J$ Dairy Technol. (2006) 59:118-25. doi: 10.1111/j.1471-0307.2006.00250.x

22. Murakami M, Tonouchi H, Takahashi R, Kitazawa H, Kawai Y, Negishi $\mathrm{H}$, et al. Structural analysis of a new anti-hypertensive peptide ( $\beta$-lactosin B) isolated from a commercial whey product. J Dairy Sci. (2004) 87:196774. doi: 10.3168/jds.S0022-0302(04)70013-2

23. Hartmann R, Meisel H. Food-derived peptides with biological activity: from research to food applications. Curr Opin Biotechnol. (2007) 18:1639. doi: 10.1016/j.copbio.2007.01.013

24. Bhandari D, Rafiq S, Gat Y, Gat P, Waghmare R, Kumar V. A review on bioactive peptides: physiological functions, bioavailability and safety. Int $\mathrm{J}$ Pept Res Ther. (2020) 26:139-50. doi: 10.1007/s10989-019-09823-5

25. Silva SV, Malcata FX. Caseins as source of bioactive peptides. Int Dairy J. (2005) 15:1-15. doi: 10.1016/j.idairyj.2004.04.009

26. Tidona F, Criscione A, Guastella AM, Zuccaro A, Bordonaro S, Marletta D. Bioactive peptides in dairy products. Ital J Anim Sci. (2009) 8:31540. doi: 10.4081/ijas.2009.315

27. Wang LS, Huang JC, Chen YL, Huang M, Zhou GH. Identification and characterization of antioxidant peptides from enzymatic hydrolysates of duck meat. J Agric Food Chem. (2015) 63:3437-44. doi: 10.1021/jf506120w

28. Jang A, Jo C, Kang K-S, Lee M. Antimicrobial and human cancer cell cytotoxic effect of synthetic angiotensin-converting enzyme (ACE) inhibitory peptides. Food Chem. (2008) 107:32736. doi: 10.1016/j.foodchem.2007.08.036

29. Lafarga T, Hayes M. Bioactive peptides from meat muscle and by-products: generation, functionality and application as functional ingredients. Meat Sci. (2014) 98:227-39. doi: 10.1016/j.meatsci.2014.05.036

30. Kim E-K, Lee S-J, Jeon B-T, Moon S-H, Kim B, Park T-K, et al. Purification and characterisation of antioxidative peptides from enzymatic hydrolysates of venison protein. Food Chem. (2009) 114:1365-70. doi: 10.1016/j.foodchem.2008.11.035

31. Ohata M, Uchida S, Zhou L, Arihara K. Antioxidant activity of fermented meat sauce and isolation of an associated antioxidant peptide. Food Chem. (2016) 194:1034-9. doi: 10.1016/j.foodchem.2015.08.089

32. Sun Y, Pan D, Guo Y, Li J. Purification of chicken breast protein hydrolysate and analysis of its antioxidant activity. Food Chem Toxicol. (2012) 50:3397404. doi: 10.1016/j.fct.2012.07.047

33. Lee SJ, Kim YS, Hwang JW, Kim EK, Moon SH, Jeon BT, Park PJ. Purification and characterization of a novel antioxidative peptide from duck skin byproducts that protects liver against oxidative damage. Food Res Int. (2012) 49:285-95. doi: 10.1016/j.foodres.2012.08.017

34. Di Bernardini R, Mullen AM, Bolton D, Kerry J, O’Neill E, Hayes M. Assessment of the angiotensin-I-converting enzyme (ACE-I) inhibitory and antioxidant activities of hydrolysates of bovine brisket sarcoplasmic proteins produced by papain and characterisation of associated bioactive peptidic fractions. Meat Sci. (2012) 90:226-35. doi: 10.1016/j.meatsci.2011.07.008

35. Adje EY, Balti R, Guillochon D, Nedjar-Arroume N. $\alpha$ 67-106 of bovine hemoglobin: a new family of antimicrobial and angiotensin I-converting enzyme inhibitory peptides. Eur Food Res Technol. (2011) 232:63746. doi: 10.1007/s00217-011-1430-z 
36. Banerjee $\mathrm{P}$, Shanthi C. Isolation of novel bioactive regions frombovine Achilles tendon collagen having angiotensin Iconverting enzyme-inhibitory properties. Process Biochem. (2012) 47:2335-46. doi: 10.1016/j.procbio.2012.09.012

37. Nedjar-Arroume N, Dubois-Delval V, Miloudi K, Daoud R, Krier F, Kouach M, et al. (2006). Isolation and characterization of four antibacterial peptides from bovine hemoglobin. Peptides 27, 20822089. doi: 10.1016/j.peptides.2006.03.033

38. Liu R, Wang M, Duan JA, Guo JM, Tang YP. Purification and identification of three novel antioxidant peptides from Cornu Bubali (water buffalo horn). Peptides. (2010) 31:786-93. doi: 10.1016/j.peptides.2010.02.016

39. Liu R, Xing L, Fu Q, Zhou GH, Zhang WG. A review of antioxidant peptides derived from meat muscle and by-products. Antioxidants. (2016) 5:32. doi: $10.3390 /$ antiox 5030032

40. Ohmori T, Nakagami T, Tanaka H, Maruyama S. Isolation of prolylendopeptidase-inhibiting peptides from bovine brain. Biochem Biophys Res Commun. (1994) 202:809-15. doi: 10.1006/bbrc.1994.2002

41. Lorenzo JM, Munekata PE, Gómez B, Barba FJ, Mora L, PérezSantaescolástica C, et al. Bioactive peptides as natural antioxidants in food products-a review. Trends Food Sci Technol. (2018) 79:13647. doi: 10.1016/j.tifs.2018.07.003

42. Liu B, Aisa HA, Yili A. Isolation and identification of two potential antioxidant peptides from sheep abomasum protein hydrolysates. Eur Food Res Technol. (2018) 244:1615-25. doi: 10.1007/s00217-018-3074-8

43. Di Bernardini R, Rai DK, Bolton D, Kerry J, O’Neill E, Mullen AM, et al. Isolation, purification and characterization of antioxidant peptidic fractions from a bovine liver sarcoplasmic protein thermolysin hydrolyzate. Peptides. (2011) 32:388-400. doi: 10.1016/j.peptides.2010.11.024

44. Gallego M, Mora L, Hayes M, Reig M, Toldrá F. Effect of cooking and in vitro digestion on the antioxidant activity of dry-cured ham by-products. Food Res Int. (2017) 97:296-306. doi: 10.1016/j.foodres.2017.04.027

45. Chou C-H, Wang S-Y, Lin Y-T, Chen Y-C. Antioxidant activities of chicken liver hydrolysates by pepsin treatment. Int J Food Sci Technol. (2014) 49:1654-62. doi: 10.1111/ijfs.12471

46. Zhang Y, Kouguchi T, Shimizu K, Sato M, Takahata Y, Morimatsu F. Chicken collagen hydrolysate reduces proinflammatory cytokine production in C57BL/6.KOR-ApoEshl Mice. J Nutr Sci Vitaminol. (2010) 56:20810. doi: 10.3177/jnsv.56.208

47. Singh BP, Vij S, Hati S. Functional significance of bioactive peptides derived from soybean. Peptides. (2014) 54:171-9. doi: 10.1016/j.peptides.2014.01.022

48. Malaguti M, Dinelli G, Leoncini E, Bregola V, Bosi S, Cicero $\mathrm{AF}$, et al. Bioactive peptides in cereals and legumes: agronomical, biochemical and clinical aspects. Int J Mol Sci. (2014) 15:2112035. doi: 10.3390/ijms151121120

49. Zhang $\mathrm{M}, \mathrm{Mu}$ TH. Identification and characterization of antioxidant peptides from sweet potato protein hydrolysates by alcalase under high hydrostatic pressure. Innov Food Sci Emerg Technol. (2017) 43:92101. doi: 10.1016/j.ifset.2017.08.001

50. Tang N, Zhuang H. Evaluation of antioxidant activities of zein protein fractions. J Food Sci. (2014) 79:2174-84. doi: 10.1111/1750-3841.12686

51. Montoya-Rodríguez A, de Mejía EG, Dia VP, Reyes-Moreno C, MilánCarrillo J. Extrusion improved the anti-inflammatory effect of amaranth (Amaranthus hypochondriacus) hydrolysates in LPS-induced human THP1 macrophage-like and mouse RAW 264.7 macrophages by preventing activation of NF-к B signaling. Mol Nutr Food Res. (2014) 58:102841. doi: 10.1002/mnfr.201300764

52. Manfredini PG, Cavanhi VAF, Costa JAV, Colla LM. Bioactive peptides and proteases: characteristics, applications and the simultaneous production in solid-state fermentation. Biocatal Biotransform. (2021) 39:360-77. doi: 10.1080/10242422.2020.1849151

53. Magro AEA, Silva LC, Rasera GB, de Castro RJS. Solid-state fermentation as an efficient strategy for the biotransformation of lentils: enhancing their antioxidant and antidiabetic potentials. Bioresour Bioproces. (2019) 6:19. doi: 10.1186/s40643-019-0273-5

54. Zhu L, Chen J, Tang X, Xiong YL. Reducing, radical scavenging, and chelation properties of in vitro digests of alcalase-treated zein hydrolysate. J Agric Food Chem. (2008) 56:2714-21. doi: 10.1021/jf703697e
55. Rizzello CG, Lorusso A, Russo V, Pinto D, Marzani B, Gobbetti M. Improving the antioxidant properties of quinoa flour through fermentation with selected autochthonous lactic acid bacteria. Int J Food Microbiol. (2017) 241:252-61. doi: 10.1016/j.ijfoodmicro.2016.10.035

56. Garza NG, Koyoc JA, Castillo JA, Zambrano EA, Ancona D, Guerrero L, et al. Biofunctional properties of bioactive peptide fractions from protein isolates of moringa seed (Moringa oleifera). J Food Sci Technol. (2017) 54:4268-76. doi: 10.1007/s13197-017-2898-8

57. González-García E, Marina ML, García MC. Plum (Prunus domestica L.) by-product as a new and cheap source of bioactive peptides: extraction method and peptides characterization. J Funct Foods. (2014) 11:42837. doi: 10.1016/j.jff.2014.10.020

58. Zaky AA, Liu Y, Han P, Ma A, Jia Y. Effect of flavorzyme digestion on the antioxidant capacities of ultra-filtrated rice bran protein hydrolyzates. J Food Proces Preserv. (2020) 44:e14551. doi: 10.1111/jfpp.14551

59. Yu M, He S, Tang M, Zhang Z, Zhu Y, Sun H. Antioxidant activity and sensory characteristics of Maillard reaction products derived from different peptide fractions of soybean meal hydrolysate. Food Chem. (2018) 243:24957. doi: 10.1016/j.foodchem.2017.09.139

60. Freitas CS, Vericimo MA, da Silva ML, da Costa GCV, Pereira PR, Paschoalin VMF, et al. Encrypted antimicrobial and antitumoral peptides recoveredfrom a protein-rich soybean (Glycine max) by-product. J Funct Foods. (2019) 54:187-98. doi: 10.1016/j.jff.2019.01.024

61. Zarei M, Forghani B, Ebrahimpour A, Abdul-hamid A. In vitro and in vivo antihypertensive activity of palm kernel cake protein hydrolysates: sequencing and characterization of potent bioactive peptides. Indus Crops Prod. (2015) 76:112-20. doi: 10.1016/j.indcrop.2015.06.040

62. Zou Z, Wang M, Wang Z, Aluko RE, He R. Antihypertensive and antioxidant activities of enzymatic wheat bran protein hydrolysates. J Food Biochem. (2020) 44:1-13. doi: $10.1111 /$ jfbc. 13090

63. Kadam D, Lele SS. Value addition of oilseed meal: a focus on bioactive peptides. J Food Measur Character. (2018) 12:44958. doi: 10.1007/s11694-017-9658-3

64. Wen C, Zhang J, Zhang H, Duan Y, Ma H. Effects of divergent ultrasound pretreatment on the structure of watermelon seed protein and the antioxidant activity of its hydrolysates. Food Chem. (2019) 299:125165. doi: 10.1016/j.foodchem.2019.125165

65. Moayedi A, Mora L, Aristoy MC, Hashemi M, Safari M, Toldrá F. ACEinhibitory and antioxidant activities of peptide fragments obtained from tomato processing by-products fermented using Bacillus subtilis: effect of amino acid composition and peptides molecular mass distribution. Appl Biochem Biotechnol. (2017) 181:48-64. doi: 10.1007/s12010-016-2198-1

66. Sun H, Yao X, Wang X, Wu Y, Liu Y, Tang J, et al. Chemical composition and in vitro antioxidant property of peptides produced from cottonseed meal by solid-state fermentation. CYTA J Food. (2015) 13:26472. doi: 10.1080/19476337.2014.948072

67. Li XX, Han LJ, Chen LJ. In vitro antioxidant activity of protein hydrolysates prepared from corn gluten meal. J Sci Food Agric. (2008) 88:16606. doi: 10.1002/jsfa.3264

68. Fazhi X, Huihui P, Yang L, Lumu L, Kun Q, Xioling D. Separation and purification of small peptides from fermented sesame meal and their antioxidant activities. Protein Pept Lett. (2014) 21:966-74. doi: 10.2174/0929866521666140411113021

69. Hai-Lun HE, Xiu-Lan C, Cai-Yun S, Yu-Zhong Z, Bai-Cheng Z. Analysis of novel angiotensin-I-converting enzyme inhibitory peptides from proteasehydrolyzed marine shrimp Acetes chinensis. J Peptide Sci. (2006) 12:72633. doi: 10.1002/psc.789

70. Kim SK, Ngo DH, Vo TS. Marine fish-derived bioactive peptides as potential antihypertensive agents. Adv Food Nutr Res. (2012) 65:24960. doi: 10.1016/B978-0-12-416003-3.00016-0

71. Zhao Y, Li B, Dong S, Liu Z, Zhao X, Wang J, et al. A novel ACE inhibitory peptide isolated from Acaudina molpadioidea hydrolysate. Peptides. (2009) 30:1028-33. doi: 10.1016/j.peptides.2009.03.002

72. Ranathunga S, Rajapakse N, Kim SK. Purification and characterization of antioxidantative peptide derived from muscle of conger eel (Conger myriaster). Eur Food Res Technol. (2006) 222:3105. doi: 10.1007/s00217-005-0079-x 
73. Suetsuna K, Ukeda H. Isolation of an octapeptide which possesses active oxygen scavenging activity from peptic digest of sardine muscle. Nipp Suis Gakk. (1999) 65:1096-9. doi: 10.2331/suisan.65.1096

74. Wu HC, Chen HM, Shiau CY. Free amino acids and peptides as related to antioxidant properties in protein hydrolysates of mackerel (Scomber austriasicus). Food Res Int. (2003) 36:949-57. doi: 10.1016/S0963-9969(03)00104-2

75. Guo H, Kouzuma Y, Yonekura M. Strauctures and properties of antioxidative peptides derived from royal jelly protein. Food Chem. (2009) 113:23845. doi: 10.1016/j.foodchem.2008.06.081

76. Hori K, Sato Y, Ito K, Fujiwara Y, Iwamoto Y, Makino H, et al. Strict specificity for high-mannose type N-glycans and primary structure of a red alga Eucheuma serra lectin. Glycobiology. (2007) 17:47991. doi: 10.1093/glycob/cwm007

77. Odaka C, Sanders ML, Crews P. Jasplakinolide induces apoptosis in various transformed cell lines by a caspase-3-like protease-dependent pathway. Clin Diagn Lab Immunol. (2000) 7:947-52. doi: 10.1128/CDLI.7.6.947-952.2000

78. Freitas VM, Rangel M, Bisson LF, Jaeger RG, Machado-Santelli GM. The geodiamolide $\mathrm{H}$, derived from brazilian sponge Geodia corticostylifera, regulates actin cytoskeleton, migration and invasion of breast cancer cells cultured in three-dimensional environment. J Cell Physiol. (2008) 216:58394. doi: $10.1002 / j c p .21432$

79. Chen J, Ryu B, Zhang Y, Liang P, Li C, Zhou C, et al. Comparison of an angiotensin-I-converting enzyme inhibitory peptide from tilapia (Oreochromis niloticus) with captopril: inhibition kinetics, in vivo effect, simulated gastrointestinal digestion and a molecular docking study. J Sci Food Agri. (2020) 100:315-24. doi: 10.1002/jsfa.10041

80. Ngo DH, Vo TS, Ryu B, Kim SK. Angiotensin-I-converting enzyme (ACE) inhibitory peptides from Pacific cod skin gelatin using ultrafiltration membranes. Process Biochem. (2016) 51:1622-8. doi: 10.1016/j.procbio.2016.07.006

81. Je JY, Qian ZJ, Byun HG, Kim SK. Purification and characterization of an antioxidant peptide obtained from tuna backbone protein by enzymatic hydrolysis. Process Biochem. (2007) 42:840-6. doi: 10.1016/j.procbio.2007.02.006

82. Mendis E, Rajapakse N, Kim SK. Antioxidant properties of a radicalscavenging peptide purified from enzymatically prepared fish skin gelatin hydrolysate. J Agric Food Chem. (2005) 53:581-7. doi: 10.1021/jf048877v

83. Wang Y, Zhu F, Han F, Wang H. Purification and characterization of antioxidative peptides from salmon protamine hydrolysate. J Food Biochem. (2008) 32:654-71. doi: 10.1111/j.1745-4514.2008.00190.x

84. Sila A, Bougatef A. Antioxidant peptides from marine by-products: isolation, identification and application in food systems. A review. J Funct Foods. (2016) 21:10-26. doi: 10.1016/j.jff.2015.11.007

85. Oh JY, Kim EA, Lee H, Kim HS, Lee JS, Jeon YJ. Antihypertensive effect of surimi prepared from olive flounder (Paralichthys olivaceus) by angiotensin-I converting enzyme (ACE) inhibitory activity and characterization of ACE inhibitory peptides. Process Biochem. (2019) 80:16470. doi: 10.1016/j.procbio.2019.01.016

86. Chi CF, Wang, B.,Wang YM, Zhang B, Deng SG. Isolation and characterization of three antioxidant peptides from protein hydrolysate of bluefin leatherjacket (Navodon septentrionalis) heads. J Funct Foods. (2015) 12:1-10. doi: 10.1016/j.jff.2014.10.027

87. Udenigwe CC, Aluko RE. Food protein-derived bioactive peptides: Production, processing, and potential health benefits. J Food Sci. (2012) 77:R11-24. doi: 10.1111/j.1750-3841.2011.02455.x

88. Bamdad F, Shin SH, Suh JW, Nimalaratne C, Sunwoo H. Anti-inflammatory and antioxidant properties of casein hydrolysate produced using high hydrostatic pressure combined with proteolytic enzymes. Molecules. (2017) 22:609. doi: 10.3390/molecules22040609

89. Hamada JS. Characterization of protein fractions of rice bran to devise effective methods of protein solubilization. Cereal Chem. (1997) 74:6628. doi: 10.1094/CCHEM.1997.74.5.662

90. Phongthai S, Homthawornchoo W, Rawdkuen S. Preparation, properties and application of rice bran protein: a review. Int Food Res J. (2017) 24:25.

91. Anal AK, Noomhorm A, Vongsawasdi P. Protein hydrolysates and bioactive peptides from seafood and crustacean waste: their extraction, bioactive properties and industrial perspectives. Mar Proteins Peptid. (2013) 36:70935. doi: 10.1002/9781118375082.ch36

92. Yan QJ, Huang LH, Sun Q, Jiang ZQ, Wu X. Isolation, identification and synthesis of four novel antioxidant peptides from rice residue protein hydrolyzed by multiple proteases. Food Chem. (2015) 179:2905. doi: 10.1016/j.foodchem.2015.01.137

93. Fabian $\mathrm{C}, \mathrm{Ju} \mathrm{YH}$. A review on rice bran protein: Its properties and extraction methods. Crit Rev Food Sci Nutr. (2011) 51:81627. doi: 10.1080/10408398.2010.482678

94. Wang M, Hettiarachchy NS, Qi M, Burks W, Siebenmorgen T. Preparation and functional properties of rice bran protein isolate. J Agric Food Chem. (1999) 47:411-6. doi: 10.1021/jf9806964

95. Amagliani L, O’Regan J, Kelly AL, O’Mahony JA. The composition, extraction, functionality and applications of rice proteins: a review. Trends Food Sci Technol. (2017) 64:1-12. doi: 10.1016/j.tifs.2017.01.008

96. Han Z, Cai MJ, Cheng JH, Sun DW. Effects of electric fields and electromagnetic wave on food protein structure and functionality: a review. Trends Food Sci Technol. (2018) 75:1-9. doi: 10.1016/j.tifs.2018. 02.017

97. Sedaghat Doost A, Nikbakht Nasrabadi M, Wu J, A'Yun Q, Van der Meeren P. Maillard conjugation as an approach to improve whey proteins functionality: a review of conventional and novel preparation techniques. Trends Food Sci Technol. (2019) 91:1-11. doi: 10.1016/j.tifs.2019.06.011

98. Urbizo-Reyes U, San Martin-Gonz’alez MF, Garcia-Bravo J, L'opez Malo Vigil A, Liceaga AM. Physicochemical characteristics of chia seed (Salvia hispanica) protein hydrolysates produced using ultrasonication followed by microwave-assisted hydrolysis. Food Hydrocol. (2019) 97:105187. doi: 10.1016/j.foodhyd.2019.105187

99. Gharibzahedi SMT, Smith B. The functional modification of legume proteins by ultrasonication: a review. Trends Food Sci Technol. (2020) 98:10716. doi: 10.1016/j.tifs.2020.02.002

100. Zhao Z-K, Mu T-H, Zhang M, Richel A. Effect of salts combined with high hydrostatic pressure on structure and gelation properties of sweet potato protein. Lebensmittel-Wissenschaft und -Technologie. (2018) 93:3644. doi: 10.1016/j.lwt.2018.03.007

101. Vanga SK, Wang J, Raghavan V. Effect of ultrasound and microwave processing on the structure, in-vitro digestibility and trypsin inhibitor activity of soymilk proteins. Lebensmittel-Wissenschaft und -Technologie. (2020) 131:109708. doi: 10.1016/j.lwt.2020.109708

102. Mesías M, Wagner M, George S, Morales FJ. Impact of conventional sterilization and ohmic heating on the amino acid profile in vegetable baby foods. Innov Food Sci Emerg Technol. (2016) 34:24-8. doi: 10.1016/j.ifset.2015.12.031

103. Pereira RN, Teixeira JA, Vicente AA, Cappato LP, da Silva Ferreira MV, da Silva Rocha R, et al. Ohmic heating for the dairy industry: a potential technology to develop probiotic dairy foods in association with modifications of whey protein structure. Curr Opin Food Sci. (2018) 22:95101. doi: 10.1016/j.cofs.2018.01.014

104. Li X, Ye C, Tian Y, Pan S, Wang L. Effect of ohmic heating on fundamental properties of protein in soybean milk. J Food Process Eng. (2018) 41:12660. doi: 10.1111/jfpe.12660

105. Sedaghat Doost A, Devlieghere F, Stevens CV, Claeys M, Van der Meeren P. Self-assembly of Tween 80 micelles as nanocargos for oregano and trans-cinnamaldehyde plant-derived compounds. Food Chem. (2020) 327:126970. doi: 10.1016/j.foodchem.2020.126970

106. Nasrabadi MN, Doost AS, Mezzenga R. Modification approaches of plant-based proteins to improve their technofunctionality and use in food products. Food Hydrocoll. (2021) 106789. doi: 10.1016/j.foodhyd.2021.106789

107. Zhang L, Wang L-J, Jiang W, Qian J-Y. Effect of pulsed electric field on functional and structural properties of canola protein by pretreating seeds to elevate oil yield. Lebensmittel-Wissenschaft und -Technologie. (2017) 84:7381. doi: 10.1016/j.lwt.2017.05.048

108. Liang R, Cheng S, Wang X. Secondary structure changes induced by pulsed electric field affect antioxidant activity of pentapeptides from pine nut (Pinus koraiensis) protein. Food Chem. (2018) 254:17084. doi: 10.1016/j.foodchem.2018.01.090 
109. Zaky AA, Shim J-H, Abd El-Aty AM. A Review on extraction, characterization, and applications of bioactive peptides from pressed black cumin seed cake. Front Nutr. (2021) 8:743909. doi: 10.3389/fnut.2021. 743909

110. Agyei D, Ongkudon CM, Wei CY, Chan AS, Danquah MK. Bioprocess challenges to the isolation and purification of bioactive peptides. Food Bioprod Proces. (2016) 98:244-56. doi: 10.1016/j.fbp.2016.02.003

111. Ibrahim $\mathrm{HR}$, Isono $\mathrm{H}$, Miyata $\mathrm{T}$. Potential antioxidant bioactive peptides from camel milk proteins. Anim Nutr. (2018) 4:27380. doi: 10.1016/j.aninu.2018.05.004

112. Gorska-Warsewicz H, Laskowski W, Kulykovets O, KudlińskaChylak A, Czeczotko M, Rejman K. Food products as sources of protein and amino acids-the case of Poland. Nutrients. (2018) 10:21977. doi: 10.3390/nu10121977

113. Toldra F, Reig M, Aristoy MC, Mora L. Generation of bioactive peptides during food processing. Food Chem. (2018) 267:395-404. doi: 10.1016/j.foodchem.2017.06.119

114. Esfandi R, Walters ME, Tsopmo A. Antioxidant properties and potential mechanisms of hydrolyzed proteins and peptides from cereals. Heliyon. (2019) 5:e01538. doi: 10.1016/j.heliyon.2019.e01538

115. Ajibola CF, Fashakin JB, Fagbemi TN, Aluko RE. Effect of peptide size on antioxidant properties of African yam bean seed (Sphenostylis stenocarpa) protein hydrolysate fractions. Int J Mol Sci. (2011) 12:6685702. doi: 10.3390/ijms12106685

116. Sarmadi BH, Ismail A. Antioxidative peptides from food proteins: a review. Peptides. (2010) 31:1949-56. doi: 10.1016/j.peptides.2010.06.020

117. Görgüç A, Gençdag E, Yilmaz FM. Bioactive peptides derived from plant origin by-products: biological activities and techno-functional utilizations in food developments-a review. Food Res Int. (2020) 136:109504. doi: 10.1016/j.foodres.2020.109504

118. Haney EF, Hancock REW. Peptide design for antimicrobial and immunomodulatory applications. Biopolymers. (2013) 100:572-83. doi: 10.1002/bip.22250

119. Yadavalli SS, Carey JN, Leibman RS, Chen AI, Stern AM, Roggiani $\mathrm{M}$, et al. Antimicrobial peptides trigger a division block in Escherichia coli through stimulation of a signalling system. Nat Commun. (2016) 7:1240. doi: $10.1038 /$ ncomms 12340

120. Kamali Alamdari E, Ehsani MR. Antimicrobial peptides derived from milk: a review. J Food Biosci Technol. (2017) 7:49-56.

121. Tang W, Zhang H, Wang L, Qian H, Qi X. Targeted separation of antibacterial peptide from protein hydrolysate of anchovy cooking wastewater by equilibrium dialysis. Food Chem. (2015) 168:115-23. doi: 10.1016/j.foodchem.2014.07.027

122. Aguilar-Toalá JE, Deering AJ, Liceaga AM. New insights into the antimicrobial properties of hydrolysates and peptide fractions derived from chia seed (Salvia hispanica L.). Probiot Antimicrob Prot. (2020) 12:157181. doi: 10.1007/s12602-020-09653-8

123. Omoni AO, Aluko RE. Effect of cationic flaxseed protein hydrolysate fractions on the in vitro structure and activity of calmodulin-dependent endothelial nitric oxide synthase. Mol Nutr Food Res. (2006) 50:95866. doi: 10.1002/mnfr.200600041

124. Remesic M, Sun Lee Y, Hruby VJ. Cyclic opioid peptides. Curr Med Chem. (2016) 23:1288-303. doi: 10.2174/09298673236661604271 23005

125. Lesniak A, Leszczynski P, Bujalska-Zadrozny M, Pick CG, Sacharczuk M. Naloxone exacerbates memory impairments and depressive-like behavior after mild traumatic brain injury (mTBI) in mice with upregulated opioid system activity. Behav Brain Res. (2017) 326:20916. doi: 10.1016/j.bbr.2017.03.015

126. Liu Z, Udenigwe CC. Role of food-derived opioid peptides in the central nervous and gastrointestinal systems. J Food Biochem. (2019) 43:17. doi: $10.1111 /$ jfbc. 12629

127. Ghelardini C, Di Cesare Mannelli L, Bianchi E. The pharmacological basis of opioids. Clin Cases Mineral Bone Metabol. (2015) 12:21921. doi: $10.11138 / \mathrm{ccmbm} / 2015.12 .3 .219$

128. Kaur J, Kumar V, Sharma K, Kaur S, Gat Y, Goyal A, et al. Opioid peptides: an overview of functional significance. Int J Pept Res Therapeut. (2020) 26:33-41. doi: 10.1007/s10989-019-09813-7
129. Pihlanto-Leppala A. Bioactive peptides derived from bovine whey proteins. Trends Food Sci Technol. (2002) 11:34756. doi: 10.1016/S0924-2244(01)00003-6

130. Noguchi T, Kato T, Wang L, Maeda Y, Ikeda H, Sato E, et al. Intracellular tumor-associated antigens represent effective targets for passive immunotherapy. Cancer Res. (2012) 72:167282. doi: 10.1158/0008-5472.CAN-11-3072

131. Kannan A, Hettiarachchy NS, Lay JO, Liyanage R. Human cancer cell proliferation inhibition by a pentapeptide isolated and characterized from rice bran. Peptides. (2010) 31:1629-34. doi: 10.1016/j.peptides.2010.05.018

132. Kim EK, Joung HJ, Kim YS, Hwang JW, Ahn CB, Jeon YJ, et al. Purification of a novel anticancer peptide from enzymatic hydrolysate of Mytilus coruscus. J Microbiol Biotechnol. (2012) 22:1381-7. doi: 10.4014/jmb.1207.07015

133. Dia VP, de Mejia EG. Lunasin induces apoptosis and modifies the expression of genes associated with extracellular matrix and cell adhesion in human metastatic colon cancer cells. Mol Nutr Food Res. (2011) 55:62334. doi: 10.1002/mnfr.201000419

134. Hwang JS, Yoo HJ, Song HJ, Kim KK, Chun YJ, Matsui T, et al. Inflammationrelated signaling pathways implicating TGF $\beta$ are revealed in the expression profiling of MCF7 cell treated with fermented soybean. Chungkookjang Nutr Cancer. (2011) 63:645-52. doi: 10.1080/01635581.2011.551987

135. Badger TM, Ronis MJJ, Simmen RCM, Simmen FA. Soy protein isolate and protection against cancer. J Am Coll Nutr. (2005) 24:146S-9S. doi: 10.1080/07315724.2005.10719456

136. Chen Z, Wang J, Liu W, Chen H. Physicochemical characterization, antioxidant and anticancer activities of proteins from four legume species. J Food Sci Technol. (2017) 54:964-72. doi: 10.1007/s13197-016-2390-x

137. Lee SY, Hur SJ. Antihypertensive peptides from animal products, marine organisms, and plants. Food Chem. (2017) 228:506-17. doi: 10.1016/j.foodchem.2017.02.039

138. Joffres MR, Hamet P, MacLean DR, L'italien GJ, Fodor G. Distribution of blood pressure and hypertension in Canada and the United States. Am J Hypertens. (2001) 14:1099-105. doi: 10.1016/S0895-7061(01)02211-7

139. Acquah C, Stefano ED, Udenigwe CC. Role of hydrophobicity in food peptide functionality and bioactivity. J Food Bioactiv. (2018) 4:8898. doi: 10.31665/JFB.2018.4164

140. Marambe PW, Shand PJ, Wanasundara JPD. An in-vitro investigation of selected biological activities of hydrolysed flaxseed (Linum usitatissimum L.) proteins. J Am Oil Chem Soc. (2008) 85:1155-64. doi: 10.1007/s11746-008-1293-z

141. Wang X, Chen H, Fu X, Li S, Wei J. A novel antioxidant and ACE inhibitory peptide from rice bran protein: biochemical characterization and molecular docking study. LWT Food Sci Technol. (2017) 75:939. doi: 10.1016/j.lwt.2016.08.047

142. Kong X, Guo M, Hua Y, Cao D, Zhang C. Enzymatic preparation of immunomodulating hydrolysates from soy proteins. Bioresour Technol. (2008) 99:8873-9. doi: 10.1016/j.biortech.2008.04.056

143. Vo T, Ryu B, Kim S. Purification of novel anti-inflammatory peptides from enzymatic hydrolysate of the edible microalgal Spirulina maxima. J Funct Foods. (2013) 5:1336-46. doi: 10.1016/j.jff.2013.05.001

144. Ngo DH, Vo TS, Ngo DN, Wijesekara I, Kim SK. Biological activities and potential health benefits of bioactive peptides derived from marine organisms. Int J Biol Macromol. (2012) 51:378-83. doi: 10.1016/j.ijbiomac.2012.06.001

145. Wu J, Majumder K, Gibbons K. Bioactive proteins and peptides from egg proteins. In: Mine Y, Li-Chan E, Jiang B, editors, Bioactive Proteins and Peptides as Functional Foods and Nutraceuticals. Oxford: Wiley-Blackwell (2010). p. 247-63. doi: 10.1002/9780813811 048.ch17

146. Kim SK, Wijesekara I. Development and biological activities of marine-derived bioactive peptides: a review. J Funct Foods. (2010) 2:1-9. doi: 10.1016/j.jff.2010.01.003

147. Zhao L, Wang X, Zhang X-L, Xie Q-F. Purification and identification of anti-inflammatory peptides derived from simulated gastrointestinal digests of velvet antler protein (Cervus elaphus Linnaeus). J Food Drug Anal. (2016) 24:376-84. doi: 10.1016/j.jfda.2015.10.003

148. Dumeus S, Shibu MA, Lin WT, Wang MF, Lai CH, Shen CY, et al. Bioactive peptide improves diet-induced hepatic fat deposition and hepatocyte 
proinflammatory response in SAMP8 ageing mice. Cell Physiol Biochem. (2018) 48:1942-52. doi: 10.1159/000492518

149. Dia VP, Bringe NA, De Mejia EG. Peptides in pepsin-pancreatin hydrolysates from commercially available soy products that inhibit lipopolysaccharideinduced inflammation in macrophages. Food Chem. (2014) 152:42331. doi: 10.1016/j.foodchem.2013.11.155

150. Shahi MM, Rashidi MR, Mahboob S, Haidari F, Rashidi B, Hanaee J. Protective effect of soy protein on collagen-induced arthritis in rat. Rheumatol Int. (2012) 32:2407-14. doi: 10.1007/s00296-011-1979-7

151. Faustino M, Veiga M, Sousa P, Costa EM, Silva S, Pintado M. Agro-food byproducts as a new source of natural food additives. Molecules. (2019) 2019:1-23. doi: 10.3390/molecules24061056

152. Lam RSH, Nickerson MT. Food proteins: a review on their emulsifying properties using a structure-function approach. Food Chem. (2013) 141:97584. doi: 10.1016/j.foodchem.2013.04.038

153. Garcia-Moreno PJ, Gregersen S, Nedamani ER, Olsen TH, Marcatili $\mathrm{P}$, Overgaard MT, et al. Identification of emulsifier potato peptides by bioinformatics: application to omega-3 delivery emulsions and release from potato industry side streams. Sci Rep. (2020) 10:1-22. doi: 10.1038/s41598-019-57229-6

154. Liu F, Wang D, Sun C, McClements DJ, Gao Y. Utilization of interfacial engineering to improve physicochemical stability of $\beta$-carotene emulsions: multilayer coatings formed using protein and protein-polyphenol conjugates. Food Chem. (2016) 205:129-39. doi: 10.1016/j.foodchem.2016.02.155

155. Tsumura K, Kugimiya W, Inouye K. Emulsifying properties of a peptide from peptic hydrolysates of soy glycinin. Food Sci Technol Res. (2005) 11:46-51. doi: 10.3136/fstr.11.46

156. Alvarez D, Delles RM, Xiong YL, Castillo M, Payne FA, Laencina J. Influence of canola-olive oils, rice bran and walnut on functionality and emulsion stability of frankfurters. LWT Food Sci Technol. (2011) 44:143542. doi: 10.1016/j.lwt.2011.01.006

157. Talukder S, Sharma DP. Development of dietary fiber rich chicken meat patties using wheat and oat bran. J Food Sci Technol. (2010) 47:2249. doi: 10.1007/s13197-010-0027-z

158. Kamani MH, Meera MS, Bhaskar N, Modi VK. Partial and total replacement of meat by plant-based proteins in chicken sausage: evaluation of mechanical, physico-chemical and sensory characteristics. J Food Sci Technol. (2019) 56:2660-9. doi: 10.1007/s13197-019-03754-1

159. Xiong T, Xiong W, Ge M, Xia J, Li B, Chen Y. Effect of high intensity ultrasound on structure and foaming properties of pea protein isolate. Food Res Int. (2018) 109:260-7. doi: 10.1016/j.foodres.2018.04.044

160. Elsohaimy SA, Refaay TM, Zaytoun MAM. Physicochemical and functional properties of quinoa protein isolate. Ann Agri Sci. (2015) 60:297305. doi: 10.1016/j.aoas.2015.10.007

161. Tibin IM, Mustafa MA. Quality attributes of beef burger patties extended with soybean flour and water melon seed cakes. J Vet Med Anim Prod. (2018) 8:1893.

162. Hidayat BT, Wea A, Andriati N. Physicochemical, sensory attributes and protein profile by SDS-PAGE of beef sausage substituted with texturized vegetable proteins. Food Res. (2018) 2:20-31. doi: 10.26656/fr.2017. 2(1). 106

163. Carvalho GRd, Milani TMG, Trinca NRR, Nagai LY, Barretto ACdaS. Textured soy protein, collagen and maltodextrin as extenders to improve the physicochemical and sensory properties of beef burger. Food Sci Technol. (2017) 37:10-6. doi: 10.1590/1678-457x.31916

164. Karami Z, Akbari-adergani B. Bioactive food derived peptides: a review on correlation between structure of bioactive peptides and their functional properties. J Food Sci Technol. (2019) 56:535-47. doi: 10.1007/s13197-018-3549-4

165. Rowayshed G, Sharaf AM, El-Faham SY, Ashour M, Zaky AA. Utilization of potato peels extract as source of phytochemicals in biscuits. J Basic Appl Res Int. (2015) 8:190-201.

166. Zaky AA, Abd El-Aty AM, Ma A, Jia Y. An overview on antioxidant peptides from rice bran proteins: extraction, identification, and applications. Crit Rev Food Sci Nutr. (2020) 2020:1-13. doi: 10.1080/10408398.2020.18 42324
167. Zaky AA, Chen Z, Qin M, Wang M, Jia Y. Assessment of antioxidant activity, amino acids, phenolic acids and functional attributes in defatted rice bran and rice bran protein concentrate. Progr Nutr. (2020) 22:e2020069. doi: $10.23751 /$ pn.v22i4.8971

168. El-Faham SY, Mohsen M, Sharaf A, Zaky A. Utilization of mango peels as a source of polyphenolic antioxidants. Curr Sci Int. (2016) 5:529-42.

169. Zaky AA, Asiamah E, El-Faham SY, Ashour MM, Sharaf A. Utilization of grape pomace extract as a source of natural antioxidant in biscuits. Eur Acad Res. (2020) 8:108-26.

170. Sohaib M, Anjum FM, Sahar A, Arshad MS, Rahman UU, Imran A, et al. Antioxidant proteins and peptides to enhance the oxidative stability of meat and meat products: a comprehensive review. Int J Food Prop. (2017) 20:2581-93. doi: 10.1080/10942912.2016.1246456

171. Samaranayaka AG, Li-Chan EC. Food-derived peptidic antioxidants: a review of their production, assessment, and potential applications. J Funct Foods. (2011) 3:229-54. doi: 10.1016/j.jff.2011.05.006

172. Nikoo M, Benjakul S, Ehsani A, Li J, Wu F, Yang N, et al. Antioxidant and cryoprotective effects of a tetrapeptide isolated from Amur sturgeon skin gelatin. J Funct Foods. (2014) 7:609-20. doi: 10.1016/j.jff.2013.12.024

173. Shahidi F, Han XQ, Synowiecki J. Production and characteristics of protein hydrolysates from capelin (Mallotus villosus). Food Chem. (1995) 53:28593. doi: 10.1016/0308-8146(95)93934-J

174. Kittiphattanabawon P, Benjakul S, Visessanguan W, Shahidi F. Gelatin hydrolysate from blacktip shark skin prepared using papaya latex enzyme: antioxidant activity and its potential in model systems. Food Chem. (2012) 135:1118-26. doi: 10.1016/j.foodchem.2012.05.080

175. Bougatef A, Nedjar-Arroume N, Manni L, Ravallec R, Barkia A, Guillochon D, et al. Purification and identification of novel antioxidant peptides from enzymatic hydrolysates of sardinelle (Sardinella aurita) by-products proteins. Food Chem. (2010) 118:559-65. doi: 10.1016/j.foodchem.2009.05.021

176. Sun J, He H, Xie BJ. Novel antioxidant peptides from fermented mushroom Ganoderma lucidum. J Agric Food Chem. (2004) 52:664652. doi: 10.1021/jf0495136

177. Yang JI, Ho HY, Chu YJ, Chow CJ. Characteristic and antioxidant activity of retorted gelatin hydrolysates from cobia (Rachycentron canadum) skin. Food Chem. (2008) 110:128-36. doi: 10.1016/j.foodchem.2008.01.072

178. Cai, L.,Wu X, Zhang Y, Li X, Ma S, Li J. Purification and characterization ofthree antioxidant peptides from protein hydrolysate of grass carp (Ctenopharyngodon idella) skin. J Funct Foods. (2015) 16:234-42. doi: 10.1016/j.jff.2015.04.042

179. Sivaraman B, Shakila RJ, Jeyasekaran G, Sukumar D, Manimaran U, Sumathi G. Antioxidant activities of squid protein hydrolysates prepared with papain using response surface methodology. Food Sci Biotechnol. (2016) 25:66572. doi: $10.1007 /$ s10068-016-0117-4

180. Shen Y, Hu R, Li Y. Antioxidant and emulsifying activities of corn gluten meal hydrolysates in oil-in-water emulsions. J Am Oil Chem Soc. (2020) 97:175-85. doi: 10.1002/aocs.12286

181. Li Y, Kong B, Liu Q, Xia X, Chen H. Improvement of the emulsifying and oxidative stability of myofibrillar protein prepared oil-in-water emulsions by addition of zein hydrolysates. Process Biochem. (2017) 53:11624. doi: 10.1016/j.procbio.2016.11.010

182. Jridi M, Lassoued I, Nasri R, Ayadi MA, Nasri M, Souissi N. Characterization and potential use of cuttlefish skin gelatin hydrolysates prepared by different microbial proteases. Biomed Res Int. (2014) 2014:1-14. doi: 10.1155/2014/461728

183. Sakanaka S, Tachibana Y, Ishihara N, Juneja LR. Antioxidant properties of casein calcium peptides and their effects on lipid oxidation in beef homogenates. J Agric Food Chem. (2005) 53:464-8. doi: 10.1021/jf04 87699

184. Peña-Ramos EA, Xiong YL. Whey and soy protein hydrolysates inhibit lipid oxidation in cooked pork patties. Meat Sci. (2003) 64:25963. doi: 10.1016/S0309-1740(02)00187-0

185. Bechaux J, Gatellier P, Le Page JF, Drillet Y, Sante-Lhoutellier V. A comprehensive review of bioactive peptides obtained from animal byproducts and their applications. Food Funct. (2019) 10:6244-66. doi: 10.1039/C9FO01546A 
186. Català-Clariana S, Benavente F, Giménez E, Barbosa J, Sanz-Nebot V. Identification of bioactive peptides in hypoallergenic infant milk formulas by CE-TOF-MS assisted by semiempirical model of electromigration behavior. Electrophoresis. (2013) 34:1886-94. doi: 10.1002/elps.201200547

187. You L, Zhao M, Regenstein JM, Ren J. In vitro antioxidant activity and in vivo anti-fatigue effect of loach (Misgurnus anguillicaudatus) peptides prepared by papain digestion. Food Chem. (2011) 124:18894. doi: 10.1016/j.foodchem.2010.06.007

188. Han B-K, Park Y, Choi H-S, Suh HJ. Hepatoprotective effects of soluble rice protein in primary hepatocytes and in mice. J Sci Food Agric. (2016) 96:685-94. doi: 10.1002/jsfa.7153

189. Zhang R, Chen J, Jiang X, Yin L, Zhang X. Antioxidant and hypoglycaemic effects of tilapia skin collagen peptide in mice. Int J Food Sci Technol. (2016) 51:2157-63. doi: 10.1111/ijfs.13193

190. De Simone C, Picariello G, Mamone G, Stiuso P, Dicitore A, Vanacore $\mathrm{D}$, et al. Characterisation and cytomodulatory properties of peptides from Mozzarella di Bufala Campana cheese whey. J Pept Sci. (2009) 15:2518. doi: 10.1002/psc.1093

191. Meisel H, FitzGerald RJ. Biofunctional peptides from milk proteins: mineral binding and cytomodulatory effects. Curr Pharm Des. (2003) 9:128996. doi: 10.2174/1381612033454847

192. Mahmoud SS, Torchilin VP. Hormetic/cytotoxic effects of Nigella sativa seed alcoholic and aqueous extracts on MCF-7 breast cancer cells alone or in combination with doxorubicin. Cell Biochem Biophys. (2013) 66:45160. doi: 10.1007/s12013-012-9493-4

193. Saisavoey T, Sangtanoo P, Reamtong O, Karnchanatat A. Antioxidant and anti-inflammatory effects of defatted rice bran (Oryza sativa L.) protein hydrolysates on raw 264.7 macrophage cells. J Food Biochem. (2016) 40:73140. doi: $10.1111 /$ jfbc. 12266

194. Chauhan V, Kanwar SS. Bioactive peptides: synthesis, functions and Biotechnological applications. In: Biotechnological Production of Bioactive Compounds, eds M. L. Verma and A. K. Chandel (Amsterdam: Elsevier). (2020). p. 107-37. doi: 10.1016/B978-0-444-64323-0.00004-7

195. Marczak ED, Usui H, Fujita H, Yang Y, Yokoo M, Lipkowski AW, et al. New antihypertensive peptides isolated from rapeseed. Peptides. (2003) 24:7918. doi: 10.1016/S0196-9781(03)00174-8

196. El-Salam MA, El-Shibiny S. Bioactive peptides of buffalo, camel, goat, sheep, mare, and yak milks and milk products. Food Rev Int. (2013) 29:123. doi: 10.1080/87559129.2012.692137

197. Reddi S, Kapila R, Ajay Kumar Dang AK, Kapila S. Evaluation of allergenic response of milk bioactive peptides using mouse mast cell. MilchwissenschaftMilk Sci Int. (2012) 67:189.

198. Ledwoń P, Errante F, Papini AM, Rovero P, Latajka R. Peptides as active ingredients: a challenge for cosmeceutical industry. Chem Biodiv. (2021) 18:e2000833. doi: 10.1002/cbdv.202000833

199. Choi HI, Park JI, Kim HJ, Kim DW, Kim SS. A novel L-ascorbic acid and peptide conjugate with increased stability and collagen biosynthesis. $B M B$ Rep. (2009) 42:743-6. doi: 10.5483/BMBRep.2009.42.11.743

200. Pickart L. The human tri-peptide GHK and tissue remodeling. J Biomater Sci Polym Ed. (2008) 19:969-88. doi: 10.1163/156856208784909435

201. Cheung RCF, Ng TB, Wong JH. Marine peptides: bioactivities and applications. Mar Drugs. (2015) 13:4006-43. doi: 10.3390/md130 74006

202. Sable R, Parajuli P, Jois S. Peptides, peptidomimetics, and polypeptides from marine sources: a wealth of natural sources for pharmaceutical applications. Mar Drugs. (2017) 15:124. doi: 10.3390/md15040124

203. Tkaczewska J, Bukowski M, Mak P. Identification of antioxidant peptides in enzymatic hydrolysates of carp (Cyprinus carpio) skin gelatin. Molecules. (2019) 24:97. doi: 10.3390/molecules 24010097

204. Aldag C, Teixeira DN, Leventhal PS. Skin rejuvenation using cosmetic products containing growth factors, cytokines, and matrikines: a review of the literature. Clin Cosmet Investig Dermatol. (2016) 9:411. doi: 10.2147/CCID.S116158

205. Schagen SK. Topical peptide treatments with effective anti-aging results. Cosmetics. (2017) 4:16. doi: 10.3390/cosmetics4020016

206. Finkley M, Appa Y, Bhandarkar S. Copper peptide and skin. In: Elsner P, Maibach H, editor, Cosmeceuticals and Active Cosmetics: Drugs vs. Cosmetics. New York NY: Marcel Dekker Press (2005). p. 549-63.
207. Lintner K, Peschard O. Biologically active peptides: from a laboratory bench curiosity to a functional skin care product. Int J Cosmet Sci. (2000) 22:20718. doi: 10.1046/j.1467-2494.2000.00010.x

208. Katayama K, Seyer JM, Raghow R, Kang AH. Regulation of extracellular matrix production by chemically synthesized subfragments of type I collagen carboxy propeptide. Biochemistry. (1991) 30:7097-104. doi: 10.1021/bi00243a009

209. Choi YL, Park EJ, Kim E, Na DH, Shin YH. Dermal stability and in vitro skin permeation of collagen pentapeptides (KTTKS and palmitoyl-KTTKS). Biomol Ther. (2014) 22:321. doi: 10.4062/biomolther.2014.053

210. Kim D-U, Chung H-C, Choi J, Sakai Y, Lee B-Y. Oral intake of lowmolecular-weight collagen peptide improves hydration, elasticity, and wrinkling in human skin: a randomized, double-blind, placebo-controlled study. Nutrients. (2018) 10:826. doi: 10.3390/nu10070826

211. Song H, Li B. Beneficial effects of collagen hydrolysate: a review on recent developments. J Sci Tech Res. (2017) 1:1-4. doi: 10.26717/BJSTR.2017.01.000217

212. Kang MC, Yumnam S, Kim SY. Oral intake of collagen peptide attenuates ultraviolet B irradiation-induced skin dehydration in vivo by regulating hyaluronic acid synthesis. Int J Mol Sci. (2018) 19:3551. doi: 10.3390/ijms19113551

213. Asserin J, Lati E, Shioya T, Prawitt J. The effect of oral collagen peptide supplementation on skin moisture and the dermal collagen network: evidence from an ex vivo model and randomized, placebo-controlled clinical trials. J Cosmet Dermatol. (2015) 14:291-301. doi: 10.1111/jocd.12174

214. Sen CK, Gordillo GM, Roy S, Kirsner R, Lambert L, Hunt TK, et al. Human skin wounds: a major and snowballing threat to public health and the economy. Wound Rep Regener. (2009) 17:763-71. doi: 10.1111/j.1524-475X.2009.00543.x

215. Heng MC. Wound healing in adult skin: aiming for perfect regeneration. Int J Dermatol. (2011) 50:1058-66. doi: 10.1111/j.1365-4632.2011.04940.x

216. Song Y, Wu C, Zhang X, Bian W, Liu N, Yin S, et al. A short peptide potentially promotes the healing of skin wound. Biosci Rep. (2019) 39:BSR20181734. doi: 10.1042/BSR20181734

217. Mustoe T. Understanding chronic wounds: a unifying hypothesis on their pathogenesis and implications for therapy. Am J Surg. (2004) 187:S6570. doi: 10.1016/S0002-9610(03)00306-4

218. Larouche J, Sheoran S, Maruyama K, Martino MM. Immune regulation of skin wound healing: mechanisms and novel therapeutic targets. Adv Wound Care. (2018) 7:209-31. doi: 10.1089/wound.2017.0761

219. Li X, Wang Y, Zou Z, Yang M, Wu C, Su Y, et al. OM-LV20, a novel peptide from odorous frog skin, accelerates wound healing in vitro and in vivo. Chem Biol Drug Design. (2018) 91:126-36. doi: 10.1111/cbdd. 13063

220. Carretero M, Escámez MJ, García M, Duarte B, Holguín A, Retamosa $\mathrm{L}$, et al. In vitro and in vivo wound healing-promoting activities of human cathelicidin LL-37. J Investig Dermatol. (2008) 128:22336. doi: 10.1038/sj.jid. 5701043

221. Ramos R, Silva JP, Rodrigues AC, Costa R, Guardão L, Schmitt F, et al. Wound healing activity of the human antimicrobial peptide LL37. Peptides. (2011) 32:1469-76. doi: 10.1016/j.peptides.2011.06.005

222. Song DW, Kim SH, Kim HH, Lee KH, Ki CS, Park YH. Multibiofunction of antimicrobial peptide-immobilized silk fibroin nanofiber membrane: implications for wound healing. Acta Biomater. (2016) 39:14655. doi: 10.1016/j.actbio.2016.05.008

223. Banerjee P, Suguna L, Shanthi C. Wound healing activity of a collagen-derived cryptic peptide. Amino Acids. (2015) 47:317-28. doi: 10.1007/s00726-014-1860-6

224. Felician FF, Yu RH, Li MZ, Li CJ, Chen HQ, Jiang Y, et al. The wound healing potential of collagen peptides derived from the jellyfish Rhopilema esculentum. Chin J Traumatol. (2019) 22:12-20. doi: 10.1016/j.cjtee.2018.10.004

225. Cheng X, Shao Z, Li C, Yu L, Raja MA, Liu C. Isolation, characterization and evaluation of collagen from jellyfish Rhopilema esculentum Kishinouye for use in hemostatic applications. PLoS ONE. (2017) 12:e0169731. doi: 10.1371/journal.pone.0169731

226. Addad S, Exposito JY, Faye C, Ricard-Blum S, Lethias C. Isolation, characterization and biological evaluation of jellyfish 
collagen for use in biomedical applications. Mar Drugs. (2011) 9:967-83. doi: 10.3390/md9060967

227. Wu G, Bazer FW, Cross HR. Land-based production of animal protein: impacts, efficiency, and sustainability. Ann N Y Acad Sci. (2014) 1328:1828. doi: 10.1111/nyas. 12566

228. Wu G, Fanzo J, Miller DD, Pingali P, Post M, Steiner JL, et al. Production and supply of high-quality food protein for human consumption: sustainability, challenges, and innovations. Ann N Y Acad Sci. (2014) 1321:119. doi: 10.1111 /nyas. 12500

229. Dieterich F, Boscolo WR, Pacheco MTB, Silva VSN, Gonçalves GS, Vidotti RM. Development and characterization of protein hydrolysates originated from animal agro industrial byproducts. J Dairy Vet Anim Res. (2014) 1:1-7. doi: 10.15406/jdvar.2014.01.00012

230. Hou Y, Wu Z, Dai Z, Wang G, Wu G. Protein hydrolysates in animal nutrition: Industrial production, bioactive peptides, and functional significance. J Anim Sci Biotechnol. (2017) 8:1-13. doi: 10.1186/s40104-017-0153-9

231. Pasupuleti VK, Holmes C, Demain AL. Applications of protein hydrolysates in biotechnology. In: Protein Hydrolysates in Biotechnology, eds V. K. PasupuletiArnold and L. Demain (New York, NY: Springer Science). (2010). p. 1-9. doi: 10.1007/978-1-4020-6674-0

232. Lalles JP, Toullec R, Pardal PB, Sissons JW. Hydrolyzed soy protein isolate sustains high nutritional performance in veal calves. J Dairy Sci. (1995) 78:194-204. doi: 10.3168/jds.S0022-0302(95)76629-2

233. Opheim M, Sterten H, Øverland M, Kjos NP. Atlantic salmon (Salmo salar) protein hydrolysate-effect on growth performance and intestinal morphometry in broiler chickens. Livest Sci. (2016) 187:138-45. doi: 10.1016/j.livsci.2016.03.005

234. Khosravi S, Rahimnejad S, Herault M, Fournier V, Lee CR, Bui HTD, et al. Effects of protein hydrolysates supplementation in low fish meal diets on growth performance, innate immunity and disease resistance of red sea bream Pagrus major. Fish Shellfish Immunol. (2015) 45:85868. doi: 10.1016/j.fsi.2015.05.039

235. Nagodawithana TW, Nelles L, Trivedi NB. Protein hydrolysates as hypoallergenic, flavors and palatants for companion animals. In: Protein Hydrolysates in Biotechnology, eds V. K. PasupuletiArnold and L. Demain (New York, NY: Springer Science). (2010). p. 191-207. doi: 10.1007/978-1-4020-6674-0_11
236. Kim SW, Van Heugten E, Ji F, Lee CH, Mateo RD. Fermented soybean meal as a vegetable protein source for nursery pigs: I. Effects on growth performance of nursery pigs. J Anim Sci. (2010) 88:21424. doi: $10.2527 /$ jas.2009-1993

237. El-Ayek MY, Gabr AA, Mehrez AZ. Influence of substituting concentrate feed mixture by Nigella sativa meal on animal performance and carcass traits of growing lambs. Egypt J Nutr Feeds. (1999) 2:265-77.

238. El-Deek AA, Hamdy SM, Attia YA, Khalifah MM. Nigella sativa seed oil meal as a source of plant protein in broiler diets. Egypt Poult Sci J. (2009) 29:39-52.

239. Doorten APS, Vd Wiel JAG, Jonker D. Safety evaluation of an IPP tripeptidecontaining milk protein hydrolysate. Food Chem Toxicol. (2009) 47:5561. doi: 10.1016/j.fct.2008.10.001

240. Anadón A, Martínez MA, Ares I, Ramos E, Martínez-Larrañaga MR, Contreras MM, et al. Acute and repeated dose (4 weeks) oral toxicity studies of two antihypertensive peptides, RYLGY and AYFYPEL, that correspond to fragments (90-94) and (143-149) from as1casein. Food Chem Toxicol. (2010) 48:1836-45. doi: 10.1016/j.fct.2010. 04.016

Conflict of Interest: The authors declare that the research was conducted in the absence of any commercial or financial relationships that could be construed as a potential conflict of interest.

Publisher's Note: All claims expressed in this article are solely those of the authors and do not necessarily represent those of their affiliated organizations, or those of the publisher, the editors and the reviewers. Any product that may be evaluated in this article, or claim that may be made by its manufacturer, is not guaranteed or endorsed by the publisher.

Copyright (๑ 2022 Zaky, Simal-Gandara, Eun, Shim and Abd El-Aty. This is an open-access article distributed under the terms of the Creative Commons Attribution License (CC BY). The use, distribution or reproduction in other forums is permitted, provided the original author(s) and the copyright owner(s) are credited and that the original publication in this journal is cited, in accordance with accepted academic practice. No use, distribution or reproduction is permitted which does not comply with these terms. 